Discussion Paper No. 10-092

\title{
Words Speak Louder Than Actions: \\ The Impact of Politics on Economic Performance
}

Steffen Osterloh

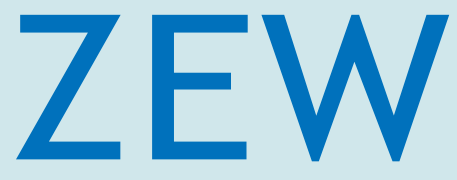

Zentrum für Europäische Wirtschaftsforschung $\mathrm{GmbH}$

Centre for European

Economic Research 
Discussion Paper No. 10-092

\title{
Words Speak Louder Than Actions: \\ The Impact of Politics on Economic Performance
}

\author{
Steffen Osterloh
}

Download this ZEW Discussion Paper from our ftp server:

ftp://ftp.zew.de/pub/zew-docs/dp/dp10092.pdf

Die Discussion Papers dienen einer möglichst schnellen Verbreitung von neueren Forschungsarbeiten des ZEW. Die Beiträge liegen in alleiniger Verantwortung der Autoren und stellen nicht notwendigerweise die Meinung des ZEW dar.

Discussion Papers are intended to make results of ZEW research promptly available to other economists in order to encourage discussion and suggestions for revisions. The authors are solely responsible for the contents which do not necessarily represent the opinion of the ZEW. 


\section{Non-technical summary}

In this paper, we present a new approach to disclose the impact of policy preferences of parties on economic growth. We derive policy preferences of parties, such as political ideology and preferences restricted to single policy dimensions, from the content analysis of party manifestos. This data is obtained from the Comparative Manifesto Project $(\mathrm{CMP})$, an international large scale project in political science that has collected the wording of thousands of election manifestos. These are coded according to the frequency of sentences devoted to 56 different policy issues, which comprise economic and non-economic issues and are regarded as proxies for the party preferences in the related political science literature. Based on this data, it is possible to calculate indices for the general left-right position as well as concerning specific policy areas that represent the political preferences of the parties or legislatures.

In the empirical section, we analyse per capita GDP growth in a panel of 23 OECD countries for the period 1971-2004. We estimate several models containing a set of typical control variables; fixed effects control for time-invariant country-specific influences. First, we follow an approach which is typical for the empirical political economics literature and employ dummy variables for the differentiation of left-wing and right-wing governments. However, we are not able to detect a significant impact of partisanship on growth rates. This implies that partisanship defined according to the broad distinction between leftwing and right-wing governments cannot be proven to affect economic growth.

Then we proceed with analyses based on 7 indices that account for the political preferences concerning different policy areas. These indicators are first tested individually in our empirical model, and then jointly in a model averaging procedure, the weighted averaged least squares (WALS) method. A strong and robust negative impact on economic growth can be detected for parties that support market interventions, whereas a positive impact can be found for parties that aim at setting incentives for business as well as those which promote technology and infrastructure. Welfare state policies are also found to have a significant negative effect in our classical estimations, but show a much weaker impact in our WALS analysis. These results are robust to several changes in specification. The consideration of programmatic profiles of parties thus allows us to identify a growth effect for certain policy areas. This underlines the importance of choosing the correct ideology measure for the analysis of partisan effects on economic outcomes. 


\section{Das Wichtigste in Kürze}

In diesem Papier wird ein neuartiger Ansatz zur Untersuchung des Einflusses von politischen Präferenzen auf die wirtschaftliche Entwicklung vorgestellt. Wir leiten diese Politikpräferenzen, welche die ideologische Ausrichtung wie auch einzelne politische Dimensionen umfassen, aus der Inhaltsanalyse von Parteiprogrammen ab. Es werden Daten vom Comparative Manifesto Project (CMP) herangezogen, welches ein großangelegtes politikwissenschaftliches Projekt darstellt, das die Texte von tausenden Wahlprogrammen gesammelt hat. Diese sind entsprechend der Häufigkeit der Nennung von Sätzen in Bezug auf 56 verschiedene Politikbereiche erfasst, die sowohl ökonomische als auch nichtökonomische Themen umfassen und in der verwandten politikwissenschaftlichen Literatur als Proxys für die Parteipräferenzen angesehen werden. Basierend auf diesen Daten ist es möglich, Indices für die allgemeine Links-rechts-Position wie auch für bestimmte Politikbereiche zu berechnen, welche die politischen Präferenzen der Parteien bzw. des Gesetzgebers darstellen.

Im empirischen Teil wird das Wachstum des Pro-Kopf-BIP in einem Panel von 23 OECDLändern für den Zeitraum 1971-2004 untersucht. Es wird eine Reihe von Modellen geschätzt, welche die typischen Kontrollvariablen enthalten; zudem kontrollieren fixe Effekte für zeitinvariante länderspezifische Einflüsse. Am Anfang folgen wir dem in der politökonomischen Literatur üblichen Ansatz und verwenden Dummyvariablen für die Differenzierung von linken und rechten Regierungen. Jedoch lässt sich auf dieser Basis kein signifikanter Einfluss der Ideologievariable nachweisen. Demnach übt politische Ideologie, sofern diese lediglich an Hand der groben Unterscheidung von linken und rechten Regierungen definiert wird, keinen nachweisbaren Effekt auf die Wachstumsraten aus.

Anschließend werden Untersuchungen auf der Basis von sieben Indices durchgeführt, welche die politischen Präferenzen in Bezug auf spezifische Politikfelder erfassen. Diese Indikatoren werden erst individuell in unserem empirischen Modell getestet, danach zusammen in einem "Model Averaging" Ansatz, der "Weighted Averaged Least Squares" (WALS) Methode. Ein starker und robuster negativer Effekt kann für solche Parteien nachgewiesen werden, die positiv gegenüber Eingriffen in das Marktgeschehen eingestellt sind, wohingegen ein positiver Einfluss für Parteien gefunden werden kann, die Anreize für Unternehmen anstreben oder Technologie und Infrastruktur propagieren. Auch für wohlfahrtsstaatliche Politiken wird in den klassischen Schätzungen ein signifikanter negativer Effekt gefunden, 
diese zeigen aber in der WALS-Analyse einen deutlich geringeren Einfluss. Diese Ergebnisse sind robust gegenüber einer Vielzahl weiterer Änderungen der Spezifikation. Die Berücksichtigung der programmatischen Profile von Parteien lässt uns demnach einen Wachstumseffekt für verschiedene Politikbereiche identifizieren. Dieser Befund unterstreicht die Bedeutung der Wahl des richtigen Ideologiemaßes bei der Untersuchung des Effekts politischer Ideologie auf ökonomische Auswirkungen. 


\title{
Words Speak Louder Than Actions: The Impact of Politics on Economic Performance
}

\author{
Steffen Osterloh* - ZEW Mannheim
}

This version: November 2010

\begin{abstract}
In this paper, a new approach to disclose the impact of politics on economic growth is presented: we use data derived from content analysis of party manifestos as measures of party preferences. In a panel of 23 OECD countries, we detect a positive impact of party support for various market-liberal policies on economic performance. In particular, we show that parties which were more concerned with market interventions and - to a lesser extent - welfare state policies impacted on growth negatively; those which proposed incentives for business as well as technology and infrastructure had a positive impact. Moreover, the robustness of the results is demonstrated in a model averaging framework.
\end{abstract}

Classification: O40, H11, P16

Keywords: economic growth, political economy, ideology, panel data, model averaging

Acknowledgement: The paper has benefitted substantially from comments by Eckhard Janeba, Friedrich Heinemann and Richard Jong-A-Pin, my colleagues at ZEW and University of Mannheim as well as participants of the public finance seminar in Mannheim, the SMYE in Luxembourg and the Second Conference on Recent Developments in Macroeconomics in Mannheim. Moreover, I thank Marc Debus for providing party manifesto data and Johannes Schoch for his valuable research assistance.

*ZEW (Centre for European Economic Research)

L 7, 1, 68161 Mannheim

Germany

Phone +496211235165

Fax +49621 1235223

Email osterloh@zew.de 


\section{Introduction}

The political environment of a democratic country can impact on the performance of the national economy in many ways. Some of these determinants of economic growth, such as the public expenditure level and structure, are easily measurable, so that their impacts on growth rates are examinable in econometric analyses without difficulty. Other channels are almost impossible to quantify, especially if their impact on economic growth is indirect, e.g. via the expectations of the market participants. In this regard, recent research provides evidence that the partisanship of the government by itself matters for the expectations of financial markets (see Snowberg et al. (2007)) and affects private consumption (Gerber and Huber (2009)). Consequently, when it comes to the overall impact of the political environment, which encompasses aspects such as the composition of the legislature and the political preferences of the parties represented in it, addressing the issue based only on one or a few observable policy indicators is impossible.

The impact of parties' policy preferences on growth is the focus of this paper. These preferences can have different meanings: in a broader sense, policy preferences are synonymous with political ideology; and in a more narrow sense, preferences are restricted to single policy dimensions. For instance, parties can be characterized according to dimensions such as market-liberal or interventionist, or regarding their preferences towards single policy issues such as welfare state policies. In this paper, we employ an innovative approach to quantify such policy preferences of parties. These are derived from the content analysis of party manifestos and it will be demonstrated in various growth regressions that the policy preferences of the legislature impact on the economic performance of the OECD countries.

The starting point of our analysis is political partisanship, which can be regarded as the most prominent proxy for political preferences. According to the partisan politics literature, politicians are not only office-motivated as implied by the Downsian model of elections, but are also interested in the political outcome. ${ }^{1}$ Consequently, politicians from different political wings - usually distinguished in left and right - differ in their political actions and in the expectations their incumbency generates among citizens. Concerning growth-relevant economic policies, partisanship can then be interpreted as the proxy for a set of preferred policies typically ascribed to the ideological wings: whereas left-wing

\footnotetext{
${ }^{1}$ Formal foundations of this literature and the conditions under which these distinctive preferences are actually reflected in policy outcomes can be found in Wittman (1977) and Calvert (1985).
} 
parties worry more about redistribution and are more inclined to intervene in markets, their right-wing counterparts tend to be more supportive of free markets and inclined to provide positive incentives to business. Based on endogenous growth theory, one may make the very simplified assumption that these left-wing policies should tend to dampen growth since they distort the capital accumulation decision of the private sector; the rightwing policies should tend to have the opposite effect.

The surprising insight provided by the literature, however, is that the partisan effect on economic performance - despite its intuitive relevance - has found almost no empirical testing until now, and in particular, no robust evidence exists. This issue will be confronted by our empirical approach. Our main innovation is the introduction of a new data source for political preferences which is derived from the quantitative analysis of party manifestos. Thus, we are able to calculate party positions not only with respect to the general left-right dimension, but also with respect to single policy dimensions.

Our approach has decisive advantages over the approaches typically taken in the partisan politics literature: we do not have to assume that a certain group of parties (i.e., leftwing or right-wing) stands for a certain set of policies, but we are able to identify the preferences of the parties concerning the particular policy areas and their changes over time. By this means, we are not only able to detect whether the overall partisanship of the legislature impacts on growth, but we are also able to identify the impact of party preferences for single policy dimensions, such as support for the welfare state or incentives for business. In this regard, our paper complements the existing literature which studies the effect of certain policy areas on economic growth based on measurable policies, such as public expenditure figures.

Our panel analysis of OECD countries since 1970 confirms that partisanship, defined only based on the party label of the government as being left-wing or right-wing, does not affect growth. Discrepancies defined as programmatic differences, however, actually affect the economic performance; and our approach allows us to identify the growth-enhancing and growth-reducing policies. A strong and robust negative impact can be detected for policies related to market interventions, whereas a positive impact can be found for policies which aim at setting incentives for business and policies promoting technology and infrastructure. These effects are shown to be robust in a number of different empirical specifications, as well as in a model averaging approach which accounts for model uncertainty, a problem inherent in growth regressions. 
The paper is organised as follows. Section 2 provides an overview over the related theory and empirical findings concerning the effect of political factors on growth. Section 3 introduces our measure for political preferences. In section 4 , the empirical approaches are introduced and our results are presented. Section 5 concludes.

\section{Literature overview}

\subsection{Channels of the impact of politics on growth}

The theoretical and the empirical growth literature constitute a natural starting point for the analysis of the impact of politics on economic performance. This strand of literature mainly focusses on determinants such as redistribution, institutional quality, public investments in infrastructure and microeconomic incentives. ${ }^{2}$ These approaches are based on endogenous growth theory ${ }^{3}$, where private capital accumulation is the relevant factor for economic growth. In this sense, any political interference in the markets which biases private incentives for capital accumulation necessarily impacts on growth. In this class of models, the growth effect of redistribution is straightforward: it reduces the incentives to accumulate capital through the tax distortions imposed on capital owners. ${ }^{4}$ Similarly, a low quality of institutions, such as a lack of property rights, reduces incentives to invest. On the other hand, governments setting positive microeconomic incentives for the private sector (such as deregulation or encouragement to start enterprises) should generate a positive impact on economic growth. Other policy areas which are discussed more controversially in the theoretical literature are public investments ${ }^{5}$ and fiscal decentralization ${ }^{6}$. In the related empirical literature, the straightforward approach to analyse the growth effects of single policy areas is the use of budgetary measures as explanatory variables, such as the size of the public sector, expenditures for different policy areas or the structure of taxation. Concerning the overall budget size, studies generally tend to find a negative impact, which gives support to the expectation that a large public sector generally impacts

\footnotetext{
${ }^{2}$ Further aspects, such as political stability or democracy, are neglected, since they play a minor role for industrialized countries.

${ }^{3}$ See Barro (1990) for the benchmark model and Baier and Glomm (2001) for an extension focussing on the effects of fiscal policy.

${ }^{4}$ Note that the relationship of redistribution and growth is much more complex in other models which are more relevant for developing countries, such as those considering capital market imperfections. These might even imply a positive effect. See Drazen (2000) for an overview over the competing approaches.

${ }^{5}$ See Irmen and Kuehnel (2009).

${ }^{6}$ See the survey in Baskaran and Feld (2009).
} 
negatively on growth. This finding is, however, not undisputed if one restricts to highly developed countries. It then largely depends on the empirical specification (see Bergh and Karlsson (2010)). ${ }^{7}$ A further important insight from the related literature is that in industrialized countries the expenditure and revenues structure are important determinants. Kneller et al. (1999) and more recently Angelopoulos et al. (2007) divide public expenditures into productive and unproductive ones and show that the former category has a positive effect on economic growth. Similarly, they show that distortionary taxation has a negative effect.

The expenditure category which has received most attention in the empirical literature is social expenditures and encompasses policies related to the size of the welfare state. Early research by Persson and Tabellini (1994) detects the expected negative effect of redistribution on growth, while further research surveyed by Drazen (2000) does not find much support for this channel. The general problem of this approach, however, is that pro-welfare state policies can take many other forms than social expenditures, such as tax policy, minimum wages or other regulations (Drazen (2000): 517). To overcome this problem, several studies use income inequality as a proxy for potential redistribution, but this literature does not obtain clear results (see, e.g., Banerjee and Duflo (2003)). Concerning public investment, Romp and de Haan (2007) review the empirical literature and conclude that most studies find a positive effect on growth.

Regulation of markets is even more difficult to measure with a catch-all indicator than to measure budgetary variables. Nicoletti and Scarpetta (2003) construct a set of indicators and detect a negative relation of product market regulation and growth. A further measurable political outcome is the degree of fiscal decentralization. In this regard, empirical results are inconsistent: Thornton (2007) finds a positive impact of decentralization, whereas Baskaran and Feld (2009), who apply more sophisticated data on decentralization, do not find a significant impact.

Whereas most of the cited works focus on rather medium to long-term effects of public policy on growth, the literature studying the speed of the effects and short-term effects is very limited. Nevertheless, most recent evidence by Romer and Romer (2010) suggests that shifts in public policy can affect economic growth rates quite fast. They find that a significant negative effect of tax increases on GDP growth in the USA can already be

\footnotetext{
${ }^{7}$ Moreover, such studies are exposed to severe methodological problems, as emphasized by Agell et al. (2006). They control for simultaneity and do not find a significant impact of public sector size in industrialized countries.
} 
detected after three quarters. Short-term studies with a more detailed perspective on fiscal policy, such as spending categories or the tax structure, are not available.

\subsection{Expectation-related effects of politics}

The short survey above was intended to demonstrate that there is a wide range of policies which can be expected to have a direct impact on growth; but these are difficult to study empirically since easily available indicators, such as expenditure categories, are not sufficient to give an overall picture of public activity. Even worse, the impact of the political environment on the economic performance might work via the expectations of the market participants. A change of the political environment, such as a change of government or an ideological shift of the legislature after an election, might have an immediate effect on these expectations, even before any new regulations or laws are made or have come into force. The resulting impact can then not be captured by the empirical approaches presented in the preceding subsection as they all focus on political actions which are actually conducted.

The existence of such an indirect impact of the political environment is probably most apparent for business expectations. Entrepreneurs who take investment or production decisions for the medium or long-term base them on expectations of the profitability, which depend on the general conditions not only in the present, but also in the future. Consequently, expectations concerning the future political actions play an important role. Empirically, Snowberg et al. (2007) show that the uncertainty in the aftermath of the U.S. presidential election 2004 impacted on several prediction markets. In particular, the rising expectation of a Republican victory had a positive effect on stock markets and interest rate expectations. Füss and Bechtel (2007) show that an increasing winning probability of right-wing parties in the German elections of 2002 had a positive effect on the stock market performance of small firms, while the winning probabilities of the left-wing had the adverse effect. Such an immediate effect of the political environment on the stock market reflects altered earning expectations. It can be assumed that changes of these expectations influence the real economy in the short term via a change in investments or the production level, albeit definite empirical evidence is missing.

Moreover, recent research in political science also detects a similar channel at the consumer's level. Based on US survey data, Gerber and Huber (2010) show empirically that consumer sentiment at the individual level is biased by the combination of the consumer's 
ideological position and the party in power. Since consumer sentiment is a main determinant of actual consumption behaviour, the immediate relevance of consumer sentiment for the real economy is straightforward. Such an effect is documented by Gerber and Huber (2009) for county-level sales data. Consequently, it is also imaginable that the political environment affects private consumption via consumer sentiment.

\subsection{Overall effect of the political environment}

The political-economic literature has always been very interested in studying whether and how the political environment in democratic societies at a particular time affects their economic performance. This is usually analysed in empirical growth models borrowed from macroeconometric approaches. Yet, the isolated testing of the single channels which were discussed in subsection 2.1 is not sufficient to get an overall impression of the impact of the political environment since political actions are not entirely quantifiable and expectation-related effects are completely neglected in these approaches.

A different approach is to focus on the political preferences of the decision maker (i.e. the legislature or government) which determine his actions, but they are difficult to break down to a catch-all indicator. A voluminous literature studies the impact of economic freedom indices and usually confirms a positive impact of market-liberal environments on growth rates (see the meta-analysis by Doucouliagos and Ulubasoglu (2006) for an overview of the findings). This literature, however, leaves many questions unanswered since the application of economic freedom indices is hardly able to differentiate between different policy areas. Consequently, by this means it is difficult to identify the growthdriving policies, especially when it comes to the impact of the political decision-making as several of the components of these indices are not in the responsibility of political decisionmakers, such as monetary policy, or have an institutional or path-dependent background which is not subject to rapid changes, such as the legal system. Moreover, a number of methodological objections are raised against this indicator and the related research, which is discussed in detail by de Haan et al. (2006).

In this paper, we focus on the partisan politics approach to public policy. According to the partisan politics literature (see Mueller (2003) for a survey), parties differ in their political preferences and, consequently, their actions. The ideological orientation is then regarded as a proxy for a set of policies which is typically related to the political wing of the party, and usually differentiates parties in left-wing and right-wing. In political 
science, this broad categorization of party positions is known as the party family approach. Some recent works demonstrate that political ideologies defined according to the party family affiliation of the government are a major determinant of several of the growth-relevant policies discussed in the previous subsection, such as social expenditures (Potrafke (2009)), market-oriented reforms (Pitlik (2007)), the tax structure (Angelopoulos et al. (2009)) or regulation of product markets (Potrafke (2010)); all of these aspects were studied for OECD countries. It is usually found that left-wing parties redistribute more and support government interventions in the economy whereas right-wing parties are assumed to pursue more business friendly policies, support free markets and protect legal rights. This might give rise to the expectation that right-wing parties should tend to have an indirect positive effect on growth, which is induced by the specific policies that they implement. This indirect effect might even be complemented by a direct one through the impact of ideology on the expectations of market participants as discussed in section 2.2 .

Yet, quite surprisingly, empirical evidence of a partisan effect on growth is very scarce given the relevance of the issue and given the high number of studies of partisan effects on fiscal policies. The notable exception is Bjørnskov (2005), who analyses decadal growth rates for 58 countries since 1970. He employs the party ideology of the biggest party in government as ideology measure. It is defined according to the party family approach, taking a value of -1 for left-wing, 0 for center and +1 for right-wing parties. He finds that countries with a longer period of right-wing governments showed better growth performance. The averaging over 10 years, however, disperses the ideological differences between the different political camps. Thus, the author stresses that this measure rather serves as an indicator for the ideological orientation of the society in a given time period.

This lack of empirical evidence for an effect of the political environment on the economic performance is striking given our considerations above, but may be explained by some issues related to the ideology measures which are applied consistently in the economic literature. First, parties differ in their positions regarding a multiplicity of policy areas. A party belonging to the social-democratic party group is on average more leftist than their rightist rival, but this does not have to be the case for all policy areas. It is easily imaginable that economic right-wing (i.e. liberal) parties take left-wing positions in noneconomic issues and vice versa. And even more so, these party group differences might obliterate more when it comes to party preferences with respect to specific, more narrowly 
defined and growth-relevant policy areas. Consequently, an aggregation to a simple leftright scale might be too simplistic in our context, even though the party family approach turns out to be suitable in detecting partisan effects in single policy areas as shown above. Moreover, it is problematic for our panel analysis that ideological measures based on the party family approach imply the equality of meaning of left-wing and right-wing in all countries. This is, however, unrealistic, as evidence from expert surveys (e.g. Benoit and Laver (2006)) or simple anecdotal evidence demonstrates (consider the positions of British New Labour and French Socialists for example). Finally, in the party family approach ideological positions are assumed to be stable over time, which can also be doubted based on survey evidence (the British Labour party, for example, shifted fundamentally towards the center under the leadership of Tony Blair).

Taking these concerns seriously, there are good reasons to explain why conventional ideology measures fail to give strong results in growth regressions, even though they are highly successful with respect to many other research questions. In particular, they do not allow the identification of the growth-promoting policy areas. As there is a multitude of political issues which can theoretically be assumed to affect growth, it is easily imaginable that some of these influences have opposite directions and, consequently, cancel out each other at the aggregate level. Therefore, in the following section we will present how measures for party preferences are obtained at a more disaggregate level. That way it is possible to differentiate between the influences of party stances in different policy areas on the overall economic performance of a country.

\section{Party Manifesto Data}

\subsection{Theoretical background}

In this paper we use data obtained from the quantitative content analysis of party manifestos. The application of this data is very common in political science, but not very established in economics, so we present some introductory remarks in the following (see e.g. Debus (2009) for a recent detailed overview on different approaches for the measurement of party ideologies). The content analysis of party manifestos is based on the saliency theory of party competition, which was pioneered by Budge et al. (1987). According to this approach, parties compete with each other over the emphasis of certain 
policy areas. Obvious examples are emphasis of environmental issues, which is typical of green parties, or emphasis of welfare state issues, which is typical of left-wing parties. These saliences of certain policy issues reflect the priorities of the parties and are then communicated to the public in their electoral campaigns. According to saliency theory, the degree of emphasis devoted to the issue is strongly related to the party's position on the issue.

Much research in political science has been devoted to the validation of manifesto data. The plausibility and reliability have been compared with other indicators of political ideology which are established in the political science literature (see Budge (2001) for an overview). One important reference are expert surveys, which have been conducted on various occasions among leading experts who located parties according to the left-right dimension as well as their stances regarding specific policy dimensions. These surveys (such as Benoit and Laver (2006)) provide very reliable data on ideological positions, but unfortunately, there are only few waves available so this data merely has a crosssectional character and is not suitable for the panel approach conducted here. McDonald and Mendes (2001) show that the general left-right dimension derived from the manifesto data is quite similar to expert surveys; consequently, they conclude that manifesto data provides valid and reliable measurements of the 'true' party positions. Even more so, they argue that manifesto data is superior to surveys concerning the measurement of policy positions with regard to single policy dimensions, such as economic and social policy, since experts are not as capable in distinguishing between these different areas. Hence, manifesto data is perfectly suitable for our purpose of identifying time-variant party preferences with regard to single, separable policy dimensions. Although it is true that manifestos are strategically written texts, it has to be considered that they are official documents, which means that party members cannot easily resile from the policies stated in the manifestos once in power without being punished by the voters or the party base (see Laver and Garry (2000)). Consequently, the ideological positions of the resulting legislature can be assessed based on the party manifestos issued prior to the election.

For several dimensions the empirical literature has already confirmed that policy preferences of legislatures or governments which were derived from party manifestos are actually correlated with various policy actions after the election. This issue has already been tackled by the very early contributions applying manifesto data. Budge and Hofferbert (1990) and Hofferbert and Budge (1992) show for the United States and the United Kingdom, 
respectively, that the emphasis of certain policy areas has a significant impact on related expenditure categories. Bräuninger (2005) studies the relationship between spending preferences and the public expenditure mix in a panel of OECD countries. He finds that the indicator for expenditure preferences, calculated as the ratio of emphasis given to social security issues to economic affairs categories, impacts on the expenditure mix as well as the overall level of expenditures. Concerning welfare state policies, Amable et al. (2006) show, based on a left-right measure derived from manifesto data, that more leftist governments react differently to productivity shocks than rightist governments. They tend to increase social expenditures, while right wing governments undertake stronger cuts of the replacement rates. Finally, Geys and Nuscheler (2010) do not use an overall left-right indicator but focus on the party preferences in policy fields related to health care. In particular, they show that the emphasis given to the category "Welfare State Expansion" $(\text { per504 })^{8}$ is a significant determinant of public spending for health care.

An impact of manifesto-based measures for party preferences for single policy areas has also been identified for some non-budgetary policy areas. Quinn and Toyoda (2007) show that the emphasis given to the category "Free Enterprise" (per401) explains changes in international capital account regulation. Duso and Röller (2003) and Duso and Seldeslachts (2010) apply manifesto data in research related to industrial economics and find that the emphasis given to the issues "Market Regulation" (per403) and "Welfare state limitation" (per505) are determinants of the entry liberalization, and hence competition, in the digital mobile telephony. Finally, evidence also exists for environmental policies: Knill et al. (2010) demonstrate that party preferences for "environmental protection" (per501) and "anti-growth economy" (per416) positively affect the number of adopted environmental policies.

\subsection{Data Characteristics}

We make use of the most prominent and comprehensive data source of party manifestos: the dataset of the Manifesto Research Group (MRG), which has been known since 1989 as the Comparative Manifesto Project (CMP). It is an international large-scale project in political science, which has collected the wording of 3,018 election manifestos from 54 countries since 1945. They are coded according to the frequency of (quasi-)sentences de-

\footnotetext{
${ }^{8}$ This is one of the 56 policy issues recorded in the CMP data set which will be presented in the following subsection 3.2. The code refers to the category number as listed in Budge et al. (2001).
} 
voted to 56 categories comprising economic and non-economic issues. Examples for such categories are "Law and Order", "Welfare State expansion" or "Free Enterprise". It is a well-established approach in political science to calculate measures of party positions for the general left-right dimension or single policy dimensions based on this data. We make use of both kinds of measures and calculate the respective indices as the parliament's 'centre of gravity', i.e. the position of the parties represented in parliament are weighted by their relative seat share (Cusack (1997)). This allows for estimating the overall position of a legislature for both the left-right dimension and policy area specific dimensions. ${ }^{9}$ The left-right dimension is already provided by the CMP dataset (see Budge et al. (2001)). It is generated by adding up the share of sentences in the manifestos dedicated to categories which are consistently ascribed to right-wing parties, and subtracting those shares devoted to categories which are typical for left-wing parties. Exemplarily, this indicator is depicted in figure 1 for the major parties in the UK, Labour Party and Conservative Party. A higher value indicates more right-wing positions taken by the party. As can be seen, the positions of both parties fluctuate over time, but the Conservatives are always "more rightist" than Labour. Interestingly, this data reflects the shift of the position of Labour Party to the centre under Tony Blair at the election of 1997 very well.

Figure 1: Positions of parties in the UK, left-right scale

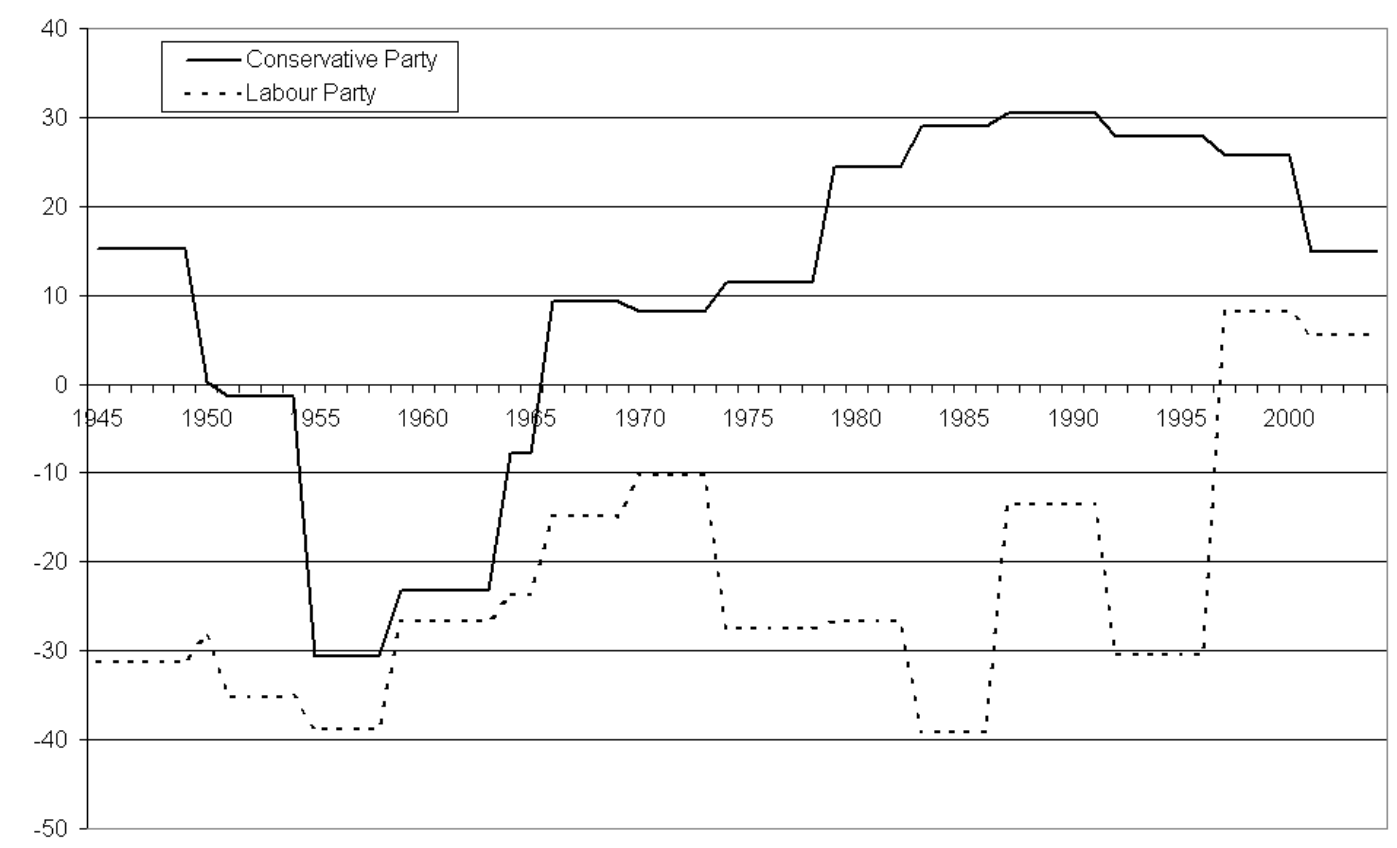

\footnotetext{
${ }^{9}$ Note that this approach is tailored for parliamentary systems with proportional representation, which constitute the majority in our sample. In subsection 4.4 we test the robustness of our results by considering that under plurality representation opposition parties tend to be marginalized.
} 
The calculation of measures for policy area specific dimensions is performed similarly by subtracting the share of negative from the share of positive statements towards the respective issue. Principally, it is also possible to use the saliencies of the single categories provided by the CMP data as explanatory variables; however, this is problematic for small categories. As discussed by Budge (2001), such categories are particularly prone to random errors and statistical noise in the codings. Moreover, several of the categories have very similar meanings (such as "Controlled Economy" and "Nationalisation"), or the categories refer to opposed statements towards the same issue (e.g. "Controlled Economy" and "Free Enterprise"). Consequently, we develop measures for policy area specific dimensions by adding up the shares of statements of similar and subtracting those of contrary categories concerning specific policy areas. In particular, we develop 8 indices, which cover 7 different policy areas (the exact assignment of the categories which are recorded in the CMP data set to our indices will be presented together with the results in the following section):

- Interventions: positive references to interventions in the markets (e.g. regulation, controlled economy), negative references to free markets

- Incentives for Business: favourable mentions of incentives for the private sector of the economy (e.g. moderate wage and tax policies, encouragement to start enterprise)

- Technology and Infrastructure: importance of science and modernisation of methods of transport and communication

- Institutions: emphasis of improving the quality of institutions (e.g. fight corruption, support democracy)

- Economic Orthodoxy: need for non-Keynesian policies (e.g. reduction of budget deficits)

- Decentralization: support for federalism or devolution

- Welfare State (narrow): support for welfare state expansion and social justice

- Welfare State (broad): broader definition of pro-welfare state policies, additionally comprising positive references to labour groups, unemployed and non-economic demographic groups 
For instance, the more frequently parties formulate statements in their manifestos that belong to intervention-related issues, the more they can be assumed to be in favour of pro-interventionist legislative proposals. The descriptive statistics for these seven policy dimensions are given in Table 9 in the appendix. The largest standard deviations can be found for Institutions and the Welfare State indices. In Table 10, the correlations of the indices are presented. It can be seen that the two welfare state measures are highly correlated due to their construction, but the other correlations are relatively modest.

\section{Empirical model and results}

Two different approaches exist in the related empirical growth literature. First, it is a well-established strategy to add the variable of interest, in our case the political variables described above, to a panel growth regression which comprises a number of further control variables. This is the typical approach of the political economic analyses cited above, such as concerning the growth effect of economic freedom indices (e.g, Berggren and Jordahl (2005)) or political ideology (Bjørnskov (2005)). Analogous to these studies, we will test our political variables in standard growth regressions. The macroeconometric literature, however, stresses that this approach might be problematic since there is no consensus how to specify the model correctly. Even though the theoretical literature predicts the relevance of certain determinants, these are often difficult to quantify. Hence, the researcher faces a high number of potential factors of influence which are, moreover, very often highly correlated. For reason of this model uncertainty, a second class of empirical approaches is often employed, which is known as model averaging approaches. Such an approach will be employed in subsection 4.2 , where the robustness of the previous results will be examined.

\subsection{Fixed effects model}

We start with the examination of our political variables in a country panel, consisting of 23 OECD countries and covering the period 1971-2004. The empirical model which will be employed throughout this section is based on the standard growth literature and includes country fixed effects. This is due to the panel structure of the data. While much of the growth literature employs cross-section data and focusses on differences between countries, we are interested in the effects due to variations in the ideological positions of 
the national legislatures. Consequently, the application of fixed effects allows us to isolate time-invariant country-specific differences, such as geographical location or cultural factors.

Our approach differs from many related papers by applying yearly data whereas most of the literature averages the variables over 5 years (and some even over a longer period). The application of yearly data is possible due to the good data availability for industrialized countries. There are further good reasons to apply yearly data in our context. As the composition of the legislature regularly shifts abruptly after elections, averaging of several years leads to a severe loss of information. This is not very problematic with other variables studied in related research, such as public expenditures, as these are quite invariable in the short term, or economic freedom indices, which are not available annually. Our variables of interest, however, fluctuate significantly over the years, so averaging would purge out much of its informative content. Nevertheless, it is regularly argued in favor of averaging in growth regressions because with the application of yearly data, business cycle movements may bias the results (see Islam (2003)). ${ }^{10}$ We address this concern by adding time fixed effects which capture international comovements of the business cycles. Moreover, we examine the robustness of our results by reestimating our model with 5 -year averages in section 4.3.

The testable model is of the following form:

$$
\Delta y_{t, i}=\beta_{0}+\beta_{1} \text { Pol }_{t-1, i}+\beta_{2} y_{t-1, i}+Z \beta_{3}+\epsilon_{i}+\eta_{t}+u_{i, t}
$$

This model includes country fixed effects $\left(\epsilon_{i}\right)$ and time fixed effects $\left(\eta_{t}\right)$. The dependent variable is the annual growth rate of real GDP per capita, which is obtained from the Penn World Tables data set. Pol ${ }_{t-1, i}$ represents the political variables which will be tested, i.e. the general left-right dimension as well as the indices for party preferences concerning policy area specific dimensions. As described above, these variables are determined from the CMP data as the centre of gravity of the respective legislature. The lagged level of per capita GDP $\left(y_{t-1, i}\right)$ is added in order to control for catch-up processes. Moreover, $Z$ represents the vector of further control variables. Due to the multitude of available variables, we present estimations for two different sets of control variables. First, we present a small model only containing basic controls for the convergence process (lagged GDP

\footnotetext{
${ }^{10}$ Yet, as Bassanini and Scarpetta (2001) argue, five-year averages are not free from cyclical influences either since there is a lack of synchronization in country business cycles.
} 
per capita), human capital (share of population in the working age) and fixed capital (investment share). Moreover, we introduce variables accounting for further possible political economic influences on growth. First, a variable indicating election years ${ }^{11}$ captures the theorized effect of political business cycles, i.e. the tendency of the incumbents to generate a boom prior to an election in order to increase their reelection probability (see Nordhaus (1975)). Second, the number of parties represented in a government is related to the "weak government hypothesis", indicating that more fragmented governments have lower assertiveness (see Roubini and Sachs (1989)). The extended set of control variables (see table 11 in the appendix for an overview of all control variables applied in the paper) introduces a number of further controls which are related to theoretical growth models and find application in related empirical works. Since we detect heteroscedasticity as well as autocorrelation of the residuals (as indicated by the Wooldridge test) in all regressions, we present t-statistics based on robust standard errors. They are clustered by country and robust to serial correlation and heteroscedasticity.

The first aspect we study is the broadest measure of ideology: the general left-right dimension. In table 1, the indicator based on manifesto data and provided in the CMP data set is contrasted with a measure which is based on the party family approach. The latter is based on the classification of the database of political institutions (DPI, see Beck et al. (2001)) and has a value of -1 if the government is completely held by left-wing parties and +1 if it is completely held by right-wing parties (coalition governments are weighted according to the parliament seats of parties). The results depicted in the table indicate that the choice of the indicator for ideology has a major impact on the results. The application of the DPI data does not detect a significant impact on growth rates, while the data obtained from party manifestos $(C M P)$ suggests that legislatures dominated by parties with a more right-wing programmatic profile positively affect the economic performance. The economic control variables perform reasonably well in these as well as in the following specifications although many of them are statistically insignificant, which should not be surprising due to the multicollinearity of several of the controls. In particular, the lagged GDP per capita has the expected negative signs reflecting convergence and is significant in most cases. The lagged size of government also turns out to have a negative impact, which is, however, not always significant. The election variable is insignificant in all cases,

\footnotetext{
${ }^{11}$ In particular, the variable takes the value of the share of months prior to the election in the election year.
} 
Table 1: Regression Results: yearly data, fixed effects

\begin{tabular}{|c|c|c|c|c|}
\hline \multirow{2}{*}{$\begin{array}{l}\text { Variable } \\
\text { Ideology }_{t-1}\end{array}$} & \multicolumn{2}{|c|}{ DPI } & \multicolumn{2}{|c|}{ CMP } \\
\hline & $\begin{array}{c}-0.135 \\
(-0.124)\end{array}$ & $\begin{array}{l}-0.089 \\
(0.137)\end{array}$ & $\begin{array}{l}0.016^{*} \\
(0.009)\end{array}$ & $\begin{array}{l}0.020^{* *} \\
(0.008)\end{array}$ \\
\hline GDP per capita $t-1$ & $\begin{array}{l}-0.104 \\
(0.090)\end{array}$ & $\begin{array}{l}-0.142^{*} \\
(0.075)\end{array}$ & $\begin{array}{l}-0.110 \\
(0.093)\end{array}$ & $\begin{array}{l}-0.145^{*} \\
(0.076)\end{array}$ \\
\hline Population share $15-64_{t}$ & $\begin{array}{c}0.234 \\
(0.155)\end{array}$ & $\begin{array}{c}0.107 \\
(0.129)\end{array}$ & $\begin{array}{c}0.252 \\
(0.154)\end{array}$ & $\begin{array}{c}0.107 \\
(0.117)\end{array}$ \\
\hline 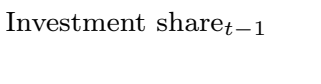 & $\begin{array}{c}0.011 \\
(0.035)\end{array}$ & $\begin{array}{c}0.004 \\
(0.042)\end{array}$ & $\begin{array}{c}0.013 \\
(0.035)\end{array}$ & $\begin{array}{c}0.007 \\
(0.041)\end{array}$ \\
\hline Election & $\begin{array}{c}0.227 \\
(0.280)\end{array}$ & $\begin{array}{c}0.183 \\
(0.254)\end{array}$ & $\begin{array}{c}0.23 \\
(0.282)\end{array}$ & $\begin{array}{c}0.183 \\
(0.257)\end{array}$ \\
\hline Number parties $_{t-1}$ & $\begin{array}{l}-0.14 \\
(0.098)\end{array}$ & $\begin{array}{l}-0.157 \\
(0.106)\end{array}$ & $\begin{array}{l}-0.156 \\
(0.097)\end{array}$ & $\begin{array}{l}-0.159 \\
(0.096)\end{array}$ \\
\hline Investment price $_{t-1}$ & & $\begin{array}{l}-0.013 \\
(0.013)\end{array}$ & & $\begin{array}{l}-0.013 \\
(0.012)\end{array}$ \\
\hline Population growth ${ }_{t}$ & & $\begin{array}{c}0.584 \\
(0.349)\end{array}$ & & $\begin{array}{c}0.583 \\
(0.353)\end{array}$ \\
\hline Public expenditure $_{t-1}$ & & $\begin{array}{l}-0.144 \\
(0.112)\end{array}$ & & $\begin{array}{l}-0.157 \\
(0.104)\end{array}$ \\
\hline Enrollment secondary $t$ & & $\begin{array}{c}0.004 \\
(0.012)\end{array}$ & & $\begin{array}{c}0.005 \\
(0.011)\end{array}$ \\
\hline Globalization $_{t}$ & & $\begin{array}{l}-0.095 \\
(0.057)\end{array}$ & & $\begin{array}{l}-0.088 \\
(0.054)\end{array}$ \\
\hline Inflation $_{t-1}$ & & $\begin{array}{l}-0.069 \\
(0.044)\end{array}$ & & $\begin{array}{l}-0.075 \\
(0.044)\end{array}$ \\
\hline Fertility rate $_{t}$ & & $\begin{array}{l}-0.910^{*} \\
(0.516)\end{array}$ & & $\begin{array}{l}-1.074^{*} \\
(0.582)\end{array}$ \\
\hline EU Dummy $t$ & & $\begin{array}{c}0.859 \\
(0.723)\end{array}$ & & $\begin{array}{c}0.776 \\
(0.694)\end{array}$ \\
\hline Urban & & $\begin{array}{l}-0.017 \\
(0.043)\end{array}$ & & $\begin{array}{c}0.004 \\
(0.046)\end{array}$ \\
\hline Constant & $\begin{array}{l}-9.729 \\
(9.734)\end{array}$ & $\begin{array}{l}12.305 \\
(9.717)\end{array}$ & $\begin{array}{c}-10.6 \\
(9.616)\end{array}$ & $\begin{array}{l}10.611 \\
(8.449)\end{array}$ \\
\hline Country FE & yes & yes & yes & yes \\
\hline Period Dummies & yes & yes & yes & yes \\
\hline Observations & 766 & 753 & 766 & 753 \\
\hline R-squared & 0.31 & 0.35 & 0.31 & 0.35 \\
\hline
\end{tabular}

Robust standard errors allowing for autocorrelation and heteroscedasticity in parentheses: $*$ Significant at the $10 \%$ level. $* *$ Significant at the $5 \%$ level. *** Significant at the $1 \%$ level.

which militates against the presence of pronounced political business cycle effects in our sample.

We then proceed with the disaggregated analysis of policy preferences. Each of the seven measures we constructed from the CMP data is tested in the two empirical models presented above. Moreover, all of the components of the indices are tested individually. The foloowing categories differ largely in their quantitative relevance (as indicated by their means): Welfare State Expansion is the largest category (about $7 \%$ of all sentences in the manifestos are devoted to this category), while smaller categories such as Nationalisation are only rarely mentioned (less than 1\%). The exact assignment of the categories recorded in the CMP data to our measures for the policy dimensions can be seen in Table 2 . 
Table 2: Summary regression results: disaggregated policy areas

\begin{tabular}{|c|c|c|c|c|c|c|}
\hline & & \multicolumn{3}{|c|}{ Small Model } & \multicolumn{2}{|c|}{ Large Model } \\
\hline & & Mean & Coefficient & Std. Dev. & Coefficient & Std. Dev. \\
\hline & Interventions & & $-0.068^{* *}$ & 0.031 & $-0.075^{* *}$ & 0.032 \\
\hline- & Free Enterprise (401) & 2.12 & 0.039 & 0.039 & 0.062 & 0.040 \\
\hline+ & Market Regulation (403) & 1.88 & -0.093 & 0.056 & $-0.143^{* * *}$ & 0.045 \\
\hline+ & Economic Planning (404) & 1.06 & -0.068 & 0.115 & -0.099 & 0.108 \\
\hline+ & Protectionism (406-407) & 0.04 & 0.022 & 0.106 & $0.179^{*}$ & 0.089 \\
\hline+ & Controlled Economy (412) & 0.86 & $-0.163^{* *}$ & 0.075 & $-0.140^{*}$ & 0.073 \\
\hline \multirow[t]{3}{*}{+} & Nationalisation (413) & 0.32 & 0.354 & 0.227 & $0.342^{*}$ & 0.169 \\
\hline & Technology and Infrastructure (411) & 5.23 & $0.113^{* *}$ & 0.050 & $0.125^{* *}$ & 0.045 \\
\hline & Economic Orthodoxy & & -0.007 & 0.034 & -0.009 & 0.029 \\
\hline+ & Economic Orthodoxy (414) & 2.94 & -0.005 & 0.033 & -0.007 & 0.028 \\
\hline \multirow[t]{2}{*}{-} & Keynesian Demand Management (409) & 0.32 & -0.074 & 0.121 & 0.023 & 0.110 \\
\hline & Incentives for Business & & $0.110^{* * *}$ & 0.029 & $0.125^{* * *}$ & 0.036 \\
\hline+ & Incentives (402) & 3.01 & $0.130^{* *}$ & 0.050 & $0.150^{* * *}$ & 0.050 \\
\hline \multirow[t]{2}{*}{+} & Productivity (410) & 2.38 & $0.115^{*}$ & 0.063 & $0.117^{*}$ & 0.064 \\
\hline & Institutions & & 0.008 & 0.017 & 0.000 & 0.016 \\
\hline+ & Freedom and Human Rights (201) & 2.31 & 0.043 & 0.044 & 0.019 & 0.043 \\
\hline+ & Democracy $(202)$ & 3.21 & 0.071 & 0.052 & 0.053 & 0.058 \\
\hline+ & Constitutionalism (203-204) & & 0.023 & 0.071 & -0.012 & 0.059 \\
\hline+ & Governmental and Adminsitrative Efficiency (303) & 3.78 & $-0.097^{* * *}$ & 0.031 & $-0.069 * *$ & 0.032 \\
\hline+ & Political Corruption (304) & 0.86 & 0.045 & 0.047 & 0.011 & 0.04 \\
\hline+ & Political Authority (305) & 3.72 & 0.015 & 0.026 & 0.011 & 0.021 \\
\hline & Law and Order (605) & 2.68 & -0.016 & 0.046 & -0.041 & 0.041 \\
\hline & Decentralisation (301-302) & 2.08 & -0.069 & 0.069 & -0.071 & 0.046 \\
\hline & Welfare State (narrow) & & -0.032 & 0.021 & $-0.057^{* * *}$ & 0.020 \\
\hline+ & Social Justice (503) & 4.56 & -0.034 & 0.051 & $-0.084^{*}$ & 0.048 \\
\hline+ & Welfare State Expansion (504) & 7.23 & -0.032 & 0.026 & -0.039 & 0.026 \\
\hline \multirow[t]{2}{*}{-} & Welfare State Limitation (505) & 0.5 & -0.043 & 0.138 & -0.102 & 0.119 \\
\hline & Welfare State (broad) & & $-0.056^{* * *}$ & 0.018 & $-0.064 * * *$ & 0.019 \\
\hline+ & Social Harmony (606) & 1.72 & -0.082 & 0.067 & -0.076 & 0.065 \\
\hline+ & Labour Groups (701-702) & 2.24 & -0.070 & 0.042 & -0.083 & 0.058 \\
\hline+ & Non-economic Demographic Groups (706) & 4.26 & -0.058 & 0.039 & -0.037 & 0.037 \\
\hline
\end{tabular}

Robust standard errors which allow for autocorrelation and heteroscedasticity: ${ }^{*}$ Significant at the $10 \%$ level. ** Significant at the $5 \%$ level. *** Significant at the $1 \%$ level.

Categories which are marked with a ' + ' are incorporated positively in the calculation of the respective index; those marked with a '-' denote categories with the opposite meaning of the index and are incorporated negatively in the calculation.

The regression results are summarised subsequently in the same table. ${ }^{12}$ It can be seen that several of the indices show a statistically significant effect on growth. First, Interventions has a negative impact, which is mainly driven by positive references to a direct government control of the economy. Similarly, a negative impact can also be detected at least for the broad indicator of Welfare State policies, whereas the results for the narrow index are also negative but not statistically robust. A positive impact is found for two indices. Technology and Infrastructure and in particular Incentives for Business exhibit a positive impact and turn out to have a positive effect at very high levels of statistical significance. The quantitative effects of the political variables are not

\footnotetext{
${ }^{12}$ The complete regression results will be provided upon request to the author.
} 
Table 3: Regression results: yearly data, fixed effects

\begin{tabular}{|c|c|c|c|c|}
\hline \multirow{2}{*}{$\begin{array}{l}\text { Variable } \\
\text { Interventions }\end{array}$} & \multicolumn{2}{|c|}{ Small Model } & \multicolumn{2}{|c|}{ Large Model } \\
\hline & $\begin{array}{c}-0.091^{* *} \\
(0.032)\end{array}$ & $\begin{array}{c}-0.087^{* * *} \\
(0.030)\end{array}$ & $\begin{array}{c}-0.091^{* * *} \\
(0.032)\end{array}$ & $\begin{array}{c}-0.088^{* * *} \\
(0.030)\end{array}$ \\
\hline Technology and Infrastructure & $\begin{array}{c}0.126^{* *} \\
(0.053)\end{array}$ & $\begin{array}{l}0.121^{* *} \\
(0.053)\end{array}$ & $\begin{array}{c}0.120^{* *} \\
(0.045)\end{array}$ & $\begin{array}{l}0.117^{* *} \\
(0.045)\end{array}$ \\
\hline Economic Orthodoxy & $\begin{array}{l}-0.025 \\
(0.035)\end{array}$ & $\begin{array}{l}-0.029 \\
(0.035)\end{array}$ & $\begin{array}{l}-0.020 \\
(0.036)\end{array}$ & $\begin{array}{l}-0.025 \\
(0.037)\end{array}$ \\
\hline Incentives for Business & $\begin{array}{c}0.099^{* * *} \\
(0.035)\end{array}$ & $\begin{array}{l}0.086^{* *} \\
(0.037)\end{array}$ & $\begin{array}{l}0.108^{* *} \\
(0.039)\end{array}$ & $\begin{array}{l}0.093^{* *} \\
(0.043)\end{array}$ \\
\hline Institutions & $\begin{array}{c}0.028 \\
(0.019)\end{array}$ & $\begin{array}{c}0.023 \\
(0.020)\end{array}$ & $\begin{array}{c}0.012 \\
(0.017)\end{array}$ & $\begin{array}{c}0.009 \\
(0.018)\end{array}$ \\
\hline Decentralisation & $\begin{array}{l}-0.068 \\
(0.075)\end{array}$ & $\begin{array}{l}-0.066 \\
(0.074)\end{array}$ & $\begin{array}{l}-0.091^{*} \\
(0.052)\end{array}$ & $\begin{array}{l}-0.083 \\
(0.050)\end{array}$ \\
\hline Welfare State (narrow) & $\begin{array}{l}-0.014 \\
(0.015)\end{array}$ & & $\begin{array}{c}-0.037^{* *} \\
(0.017)\end{array}$ & \\
\hline Welfare State (broad) & & $\begin{array}{l}-0.026 \\
(0.016)\end{array}$ & & $\begin{array}{l}-0.034^{*} \\
(0.018)\end{array}$ \\
\hline GDP per capita ${ }_{t-1}$ & $\begin{array}{l}-0.123 \\
(0.087)\end{array}$ & $\begin{array}{l}-0.129 \\
(0.085)\end{array}$ & $\begin{array}{c}-0.182^{* *} \\
(0.074)\end{array}$ & $\begin{array}{c}-0.190^{* *} \\
(0.072)\end{array}$ \\
\hline Population share $15-64_{t}$ & $\begin{array}{l}0.255^{*} \\
(0.143)\end{array}$ & $\begin{array}{l}0.252^{*} \\
(0.137)\end{array}$ & $\begin{array}{c}0.147 \\
(0.109)\end{array}$ & $\begin{array}{c}0.127 \\
(0.104)\end{array}$ \\
\hline 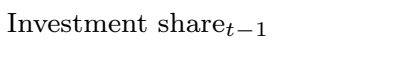 & $\begin{array}{c}0.002 \\
(0.032)\end{array}$ & $\begin{array}{c}0.005 \\
(0.032)\end{array}$ & $\begin{array}{l}-0.004 \\
(0.038)\end{array}$ & $\begin{array}{l}-0.000 \\
(0.038)\end{array}$ \\
\hline Election & $\begin{array}{c}0.280 \\
(0.282)\end{array}$ & $\begin{array}{l}0.275 \\
(0.283)\end{array}$ & $\begin{array}{c}0.219 \\
(0.266)\end{array}$ & $\begin{array}{l}0.219 \\
(0.265)\end{array}$ \\
\hline Number parties $_{t-1}$ & $\begin{array}{l}-0.206 \\
(0.121)\end{array}$ & $\begin{array}{l}-0.204 \\
(0.120)\end{array}$ & $\begin{array}{l}-0.207^{*} \\
(0.110)\end{array}$ & $\begin{array}{l}-0.209^{*} \\
(0.110)\end{array}$ \\
\hline Investment price $_{t-1}$ & & & $\begin{array}{l}-0.016 \\
(0.012)\end{array}$ & $\begin{array}{l}-0.014 \\
(0.012)\end{array}$ \\
\hline Population growth $_{t}$ & & & $\begin{array}{l}0.598^{*} \\
(0.345)\end{array}$ & $\begin{array}{l}0.596^{*} \\
(0.338)\end{array}$ \\
\hline Public expenditure $_{t-1}$ & & & $\begin{array}{l}-0.176^{*} \\
(0.087)\end{array}$ & $\begin{array}{l}-0.171^{*} \\
(0.089)\end{array}$ \\
\hline Enrollment secondary $t$ & & & $\begin{array}{l}0.001 \\
(0.010)\end{array}$ & $\begin{array}{c}0.002 \\
(0.009)\end{array}$ \\
\hline Globalization $_{t}$ & & & $\begin{array}{c}-0.115^{* *} \\
(0.048)\end{array}$ & $\begin{array}{c}-0.117^{* *} \\
(0.047)\end{array}$ \\
\hline Inflation $_{t-1}$ & & & $\begin{array}{l}-0.077^{*} \\
(0.038)\end{array}$ & $\begin{array}{l}-0.075^{*} \\
(0.038)\end{array}$ \\
\hline Fertility rate $t$ & & & $\begin{array}{c}-1.026^{* *} \\
(0.448)\end{array}$ & $\begin{array}{c}-1.041^{* *} \\
(0.466)\end{array}$ \\
\hline EU Dummy & & & $\begin{array}{c}0.440 \\
(0.647)\end{array}$ & $\begin{array}{c}0.440 \\
(0.629)\end{array}$ \\
\hline Urban & & & $\begin{array}{l}-0.012 \\
(0.046)\end{array}$ & $\begin{array}{l}-0.016 \\
(0.046)\end{array}$ \\
\hline Constant & $\begin{array}{r}-11.426 \\
(9.028) \\
\end{array}$ & $\begin{array}{r}-10.492 \\
(8.599) \\
\end{array}$ & $\begin{array}{l}12.047 \\
(8.793) \\
\end{array}$ & $\begin{array}{r}15.049^{*} \\
(8.389) \\
\end{array}$ \\
\hline Country FE & yes & yes & yes & yes \\
\hline Period Dummies & yes & yes & yes & yes \\
\hline Observations & 766 & 766 & 753 & 753 \\
\hline R-squared & 0.34 & 0.35 & 0.39 & 0.39 \\
\hline
\end{tabular}

Robust standard errors allowing for autocorrelation and heteroscedasticity in parentheses: * Significant at the $10 \%$ level. ** Significant at the $5 \%$ level. *** Significant at the $1 \%$ level.

negligible: for all of these variables, a one-standard-deviation causes an absolute change of the subsequent annual growth rate by about $0.4 \%$. No robust results are found for the other measures, i.e. Decentralization, Institutions and Economic Orthodoxy. 
Finally, in Table 3, the 7 measures derived from the manifesto data are jointly tested in our two growth models. The results largely confirm the findings from the individual analyses. Again, Incentives for Business and Technology and Infrastructure are consistently found to have a positive impact on growth rates and the negative impact of Interventions turns out to be robust as well. In contrast to this, the measures for Welfare State preferences do not yield significant results in every case.

\subsection{Model Averaging}

Approaches which are not restricted to the testing of few regressors but attach a multiplicity of explanatory variables enjoy increasing popularity in empirical macroeconomic research. They become necessary due to the "open-endedness" of growth theories, which denotes that the validity of one causal theory does not imply that other theories are false (see Brock and Durlauf (2001) for example). Consequently, the huge number of possible growth determinants and the even bigger number of available explanatory variables allows the estimation of millions of possible combinations of regressors. Durlauf et al. (2005) find in their survey a total number of more than 140 growth determinants which are considered in the empirical literature. This problem has motivated the development of several approaches which allow for checking the robustness of regressors given this model uncertainty. Most notably, the model averaging approaches by Sala-i-Martin et al. (2004) and Durlauf et al. (2008) incorporate a huge number of potential growth determinants in order to study the relevance of competing theoretical models.

Due to the prominence of these techniques in the related macroeconomic growth literature, a model averaging approach is applied in the following in order to demonstrate the robustness of the findings from the previous estimations. In an approach similar to ours, Bergh and Karlsson (2010) validate the robustness of their explanatory variables - components of the economic freedom index and globalization - in a BACE (Bayesian averaging of classical estimates) approach borrowed from Sala-i-Martin et al. (2004).

In the following, a rather new model averaging technique introduced by Magnus et al. (2010) is applied, which is known as weighted average least squares (WALS). This method is similar to classical Bayesian model averaging techniques, but has some theoretical and computational advantages as demonstrated in their article. Moreover, the code provided by the authors ${ }^{13}$ is the first to allow the definition of a subset of explanatory variables

\footnotetext{
${ }^{13}$ The MATLAB code can be downloaded at http://center.uvt.nl/staff/magnus/wals/.
} 
as 'focus' regressors which always stay in the model. Thus, we can insert time-fixed and country-fixed effects, which is a minor innovation for the model averaging literature usually applying cross-section data.

\section{Table 4: Regression results: WALS approach}

\begin{tabular}{|c|c|c|c|}
\hline Variable & Coefficient & Standard Deviation & t-ratios \\
\hline Inflation $_{t-1}$ & -0.059 & 0.017 & -3.482 \\
\hline Globalization $_{t}$ & -0.086 & 0.025 & -3.378 \\
\hline GDP per capita $t-1$ & -0.144 & 0.044 & -3.264 \\
\hline Technology and Infrastructure & 0.092 & 0.033 & 2.788 \\
\hline Interventions & -0.079 & 0.031 & -2.565 \\
\hline Incentives for Business & 0.073 & 0.029 & 2.552 \\
\hline Public expenditure $_{t-1}$ & -0.164 & 0.064 & -2.547 \\
\hline Population growth g $_{t}$ & 0.403 & 0.232 & 1.734 \\
\hline Investment price $t-1$ & -0.012 & 0.007 & -1.608 \\
\hline Number Parties & -0.138 & 0.097 & -1.414 \\
\hline Fertility rate $_{t}$ & -0.691 & 0.508 & -1.361 \\
\hline Decentralisation & -0.064 & 0.049 & -1.324 \\
\hline Population share $15-64_{t}$ & 0.114 & 0.092 & 1.241 \\
\hline $\mathrm{EU}_{t}$ & 0.322 & 0.354 & 0.909 \\
\hline Welfare State (narrow) & -0.022 & 0.028 & -0.786 \\
\hline Economic Orthodoxy & -0.021 & 0.031 & -0.681 \\
\hline Welfare State (broad) & -0.016 & 0.024 & -0.657 \\
\hline Election $_{t}$ & 0.137 & 0.213 & 0.643 \\
\hline Institutions & 0.005 & 0.014 & 0.346 \\
\hline Schooling $_{t}$ & 0.002 & 0.008 & 0.32 \\
\hline $\operatorname{Urban}_{t}$ & -0.008 & 0.043 & -0.177 \\
\hline Investment $_{t-1}$ & -0.003 & 0.018 & -0.158 \\
\hline
\end{tabular}

The estimation results are given in Table 4 . The variables representing the policy preferences have the same signs as in the previous regressions. We compute t-ratios in order to compare the relative importance of the regressors, which are arranged according to the absolute values of the t-ratios. Three of the political variables show a high robustness: Incentives for Business, Technology and Infrastructure and Interventions. These are the very same variables found to be robustly correlated with economic performance in the approaches presented above. Only three further control variables are found to be as important, with inflation in first place. The other indices derived from party preferences, including both welfare state policies indicators, are found to be of minor importance.

\subsection{Controlling for short-term variability}

Although there are good arguments to stick to annual regressions due to the characteristics of our data, we check the robustness of our results by averaging all variables over 5-year periods. The following specifications comprise a panel with the same variables which were used before. They are all averaged over 5 years, with lagged GDP per capita being 
the only exception. The last enters the regressions with its value in the initial year of the respective 5 year period. This approach makes our results highly comparable to the existing literature and ensures that our previous results are not biased due to the existence of short-term business cycle effects.

\section{Table 5: Regression results: five year averages, fixed effects}

\begin{tabular}{|c|c|c|c|c|c|c|}
\hline Left-right (CMP) & $\begin{array}{c}0.029^{* *} \\
0.014\end{array}$ & & & & & \\
\hline Interventions & & $\begin{array}{c}-0.115^{* *} \\
(0.047)\end{array}$ & & & & $\begin{array}{c}-0.123^{* *} \\
(0.045)\end{array}$ \\
\hline Technology and Infrastructure & & & $\begin{array}{c}0.112^{* *} \\
(0.052)\end{array}$ & & & $\begin{array}{c}0.089 \\
(0.052)\end{array}$ \\
\hline Incentives for Business & & & & $\begin{array}{c}0.155^{* * *} \\
(0.038)\end{array}$ & & $\begin{array}{c}0.132^{* *} \\
(0.053)\end{array}$ \\
\hline Welfare State (broad) & & & & & $\begin{array}{c}-0.067^{* *} \\
(0.027)\end{array}$ & $\begin{array}{l}-0.023 \\
(0.033)\end{array}$ \\
\hline Economic Orthodoxy & & & & & & $\begin{array}{l}-0.031 \\
(0.042)\end{array}$ \\
\hline Institutions & & & & & & $\begin{array}{c}0.007 \\
(0.031)\end{array}$ \\
\hline Decentralisation & & & & & & $\begin{array}{l}-0.074 \\
(0.089)\end{array}$ \\
\hline GDP per capita $t-1$ & $\begin{array}{l}-0.168^{*} \\
(0.085)\end{array}$ & $\begin{array}{l}-0.156^{*} \\
(0.081)\end{array}$ & $\begin{array}{l}-0.136 \\
(0.079)\end{array}$ & $\begin{array}{l}-0.159^{*} \\
(0.077)\end{array}$ & $\begin{array}{c}-0.172^{* *} \\
(0.082)\end{array}$ & $\begin{array}{c}-0.173^{* *} \\
(0.069)\end{array}$ \\
\hline Population share $15-64_{t}$ & $\begin{array}{c}0.039 \\
(0.127)\end{array}$ & $\begin{array}{c}0.034 \\
(0.122)\end{array}$ & $\begin{array}{l}0.252^{*} \\
(0.143)\end{array}$ & $\begin{array}{c}0.056 \\
(0.123)\end{array}$ & $\begin{array}{c}0.032 \\
(0.122)\end{array}$ & $\begin{array}{c}0.064 \\
(0.103)\end{array}$ \\
\hline Investment share $_{t-1}$ & $\begin{array}{c}0.075 \\
(0.069)\end{array}$ & $\begin{array}{c}0.088 \\
(0.062)\end{array}$ & $\begin{array}{c}0.063 \\
(0.065)\end{array}$ & $\begin{array}{c}0.071 \\
(0.066)\end{array}$ & $\begin{array}{c}0.080 \\
(0.068)\end{array}$ & $\begin{array}{c}0.059 \\
(0.057)\end{array}$ \\
\hline Number parties $_{t-1}$ & $\begin{array}{l}-0.205 \\
(0.182\end{array}$ & $\begin{array}{l}-0.214 \\
(0.176)\end{array}$ & $\begin{array}{l}-0.208 \\
(0.168)\end{array}$ & $\begin{array}{l}-0.153 \\
(0.148)\end{array}$ & $\begin{array}{l}-0.145 \\
(0.175)\end{array}$ & $\begin{array}{c}-0.180 \\
0.194\end{array}$ \\
\hline Investment price $t-1$ & $\begin{array}{c}0.006 \\
(0.010)\end{array}$ & $\begin{array}{c}0.005 \\
(0.011)\end{array}$ & $\begin{array}{l}-0.001 \\
(0.011)\end{array}$ & $\begin{array}{c}0.011 \\
(0.010)\end{array}$ & $\begin{array}{l}-0.001 \\
(0.011)\end{array}$ & $\begin{array}{c}0.006 \\
(0.013)\end{array}$ \\
\hline Population growth ${ }_{t}$ & $\begin{array}{c}0.621 \\
(0.604)\end{array}$ & $\begin{array}{c}0.643 \\
(0.607)\end{array}$ & $\begin{array}{c}0.507 \\
(0.618)\end{array}$ & $\begin{array}{c}0.526 \\
(0.590)\end{array}$ & $\begin{array}{c}0.532 \\
(0.630)\end{array}$ & $\begin{array}{c}0.662 \\
(0.522)\end{array}$ \\
\hline Public expenditure $_{t-1}$ & $\begin{array}{c}-0.246^{* *} \\
(0.107)\end{array}$ & $\begin{array}{c}-0.230^{* *} \\
(0.100)\end{array}$ & $\begin{array}{c}-0.248^{* *} \\
(0.107)\end{array}$ & $\begin{array}{c}-0.277^{* *} \\
(0.109)\end{array}$ & $\begin{array}{c}-0.257^{* *} \\
(0.104)\end{array}$ & $\begin{array}{c}-0.278^{* *} \\
(0.105)\end{array}$ \\
\hline Enrollment secondary $_{t}$ & $\begin{array}{l}0.021^{*} \\
(0.011)\end{array}$ & $\begin{array}{l}0.024^{*} \\
(0.012)\end{array}$ & $\begin{array}{c}0.009 \\
(0.011)\end{array}$ & $\begin{array}{c}0.018 \\
(0.012)\end{array}$ & $\begin{array}{l}0.023^{*} \\
(0.011)\end{array}$ & $\begin{array}{c}0.018 \\
(0.013)\end{array}$ \\
\hline Globalization $_{t}$ & $\begin{array}{l}-0.055 \\
(0.058)\end{array}$ & $\begin{array}{l}-0.057 \\
(0.052)\end{array}$ & $\begin{array}{l}-0.055 \\
(0.057)\end{array}$ & $\begin{array}{l}-0.072 \\
(0.057)\end{array}$ & $\begin{array}{l}-0.044 \\
(0.053)\end{array}$ & $\begin{array}{l}-0.084 \\
(0.051)\end{array}$ \\
\hline Inflation $_{t-1}$ & $\begin{array}{c}-0.090^{* *} \\
(0.039)\end{array}$ & $\begin{array}{c}-0.078^{* *} \\
(0.036)\end{array}$ & $\begin{array}{c}-0.082^{* *} \\
(0.032)\end{array}$ & $\begin{array}{c}-0.095^{* *} \\
(0.038)\end{array}$ & $\begin{array}{c}-0.081^{* *} \\
(0.034)\end{array}$ & $\begin{array}{c}-0.092^{* *} \\
0.034\end{array}$ \\
\hline Fertility rate $t$ & $\begin{array}{l}-1.030 \\
(0.798)\end{array}$ & $\begin{array}{l}-1.090 \\
(0.708)\end{array}$ & $\begin{array}{l}-0.532 \\
(0.740)\end{array}$ & $\begin{array}{l}-0.595 \\
(0.646)\end{array}$ & $\begin{array}{l}-0.876 \\
(0.739)\end{array}$ & $\begin{array}{l}-1.053 \\
(0.697)\end{array}$ \\
\hline Urban & $\begin{array}{c}0.094 \\
(0.058)\end{array}$ & $\begin{array}{c}0.071 \\
(0.052)\end{array}$ & $\begin{array}{c}0.082 \\
(0.057)\end{array}$ & $\begin{array}{l}0.018^{*} \\
(0.066)\end{array}$ & $\begin{array}{l}0.091^{*} \\
(0.049)\end{array}$ & $\begin{array}{c}0.108 \\
(0.064)\end{array}$ \\
\hline Constant & $\begin{array}{c}1.738 \\
(0.058)\end{array}$ & $\begin{array}{c}1.703 \\
(8.097)\end{array}$ & $\begin{array}{c}2.746 \\
(9.347)\end{array}$ & $\begin{array}{l}-1.626 \\
(8.252)\end{array}$ & $\begin{array}{c}2.817 \\
(8.131)\end{array}$ & $\begin{array}{c}1.906 \\
(7.869)\end{array}$ \\
\hline Country FE & yes & yes & yes & yes & yes & yes \\
\hline Period Dummies & yes & yes & yes & yes & yes & yes \\
\hline Observations & 135 & 135 & 135 & 135 & 135 & 135 \\
\hline R-squared & 0.52 & 0.53 & 0.52 & 0.54 & 0.53 & 0.60 \\
\hline
\end{tabular}

The sample now covers the period 1970-2000 and contains the full set of control variables. The results, which are presented in Table 5, show few qualitative changes compared 
to the previous results. In particular, the overall left-right indicator is still significant. The measures for the policy preferences also respond quite robustly to the modification of the specification. The variables previously found to be relevant for economic performance - Interventions, Technology and Infrastructure and Incentives for Business - have the identical signs as in the regressions using yearly data and are statistically significant when tested individually.

\subsection{Correcting for plurality systems}

Until now, we applied our political measures capturing the relative party strengths in the legislature consistently. These measures, however, might be inadequate for Westminsterstyle parliaments, in which strong one-party governments dominate the political agenda. For that reason, in the regressions depicted in Table 6 we consider the government centre of gravity instead of the parliament centre of gravity for those countries which are classified as plurality systems. ${ }^{14}$

The results are qualitatively in line with those obtained with the original political measures in section 4.1. The main difference can be observed for the coefficient of the general left-right dimensions which declines and becomes insignificant. The indices for preferences with respect to disaggregated policy areas turn out to be more robust when the government positions are considered for plurality systems and show quantitatively similar results as before.

\subsection{Potential endogeneity}

Finally, we address the potential endogeneity of our political variables. Obviously, the composition of the legislature is not exogenously assigned, since it is the result of elections. These election outcomes might be affected by the national economic situation, so this issue has to be taken serious. The following causal chain might then bias the previous results: the citizens of a country in recession might be more inclined to vote for more economic liberal parties (see Stevenson (2001) for evidence in this direction). Since yearly growth rates can be assumed to be autocorrelated positively to a certain degree, this would imply that the incumbency of these parties is correlated with rather low growth rates immediately after the election.

\footnotetext{
${ }^{14} \mathrm{We}$ applied the classification introduced by the DPI.
} 
Table 6: Regression results: government positions for plurality systems

\begin{tabular}{|c|c|c|c|c|c|c|}
\hline Left-right (CMP) & $\begin{array}{c}0.006 \\
(0.005)\end{array}$ & & & & & \\
\hline Interventions & & $\begin{array}{l}-0.043 \\
(0.031)\end{array}$ & & & & $\begin{array}{c}-0.049^{*} \\
(0.026)\end{array}$ \\
\hline Technology and Infrastructure & & & $\begin{array}{c}0.103^{* * *} \\
(0.034)\end{array}$ & & & $\begin{array}{c}0.091^{* *} \\
(0.033)\end{array}$ \\
\hline Incentives for Business & & & & $\begin{array}{c}0.091^{* * *} \\
(0.026)\end{array}$ & & $\begin{array}{c}0.059^{* *} \\
(0.028)\end{array}$ \\
\hline Welfare State (broad) & & & & & $\begin{array}{c}-0.046^{* *} \\
(0.020)\end{array}$ & $\begin{array}{c}-0.031^{*} \\
(0.016)\end{array}$ \\
\hline Economic Orthodoxy & & & & & & $\begin{array}{l}-0.033 \\
(0.021)\end{array}$ \\
\hline Institutions & & & & & & $\begin{array}{c}0.002 \\
(0.015)\end{array}$ \\
\hline Decentralisation & & & & & & $\begin{array}{l}-0.075 \\
(0.046)\end{array}$ \\
\hline GDP per capita $t-1$ & $\begin{array}{c}-0.143^{*} \\
(0.075)\end{array}$ & $\begin{array}{c}-0.145^{*} \\
(0.076)\end{array}$ & $\begin{array}{c}-0.152^{* *} \\
(0.069)\end{array}$ & $\begin{array}{c}-0.160^{* *} \\
(0.076)\end{array}$ & $\begin{array}{c}-0.152^{* *} \\
(0.072)\end{array}$ & $\begin{array}{c}-0.179^{* *} \\
(0.071)\end{array}$ \\
\hline Population share $15-64_{t}$ & $\begin{array}{c}0.092 \\
(0.126)\end{array}$ & $\begin{array}{c}0.109 \\
(0.122)\end{array}$ & $\begin{array}{c}0.091 \\
(0.129)\end{array}$ & $\begin{array}{c}0.104 \\
(0.117)\end{array}$ & $\begin{array}{c}0.092 \\
(0.116)\end{array}$ & $\begin{array}{c}0.094 \\
(0.115)\end{array}$ \\
\hline Investment share $_{t-1}$ & $\begin{array}{c}0.006 \\
(0.041)\end{array}$ & $\begin{array}{c}0.005 \\
(0.039)\end{array}$ & $\begin{array}{c}0.002 \\
(0.041)\end{array}$ & $\begin{array}{c}0.004 \\
(0.041)\end{array}$ & $\begin{array}{c}0.008 \\
(0.039)\end{array}$ & $\begin{array}{c}0.003 \\
(0.038)\end{array}$ \\
\hline Election & $\begin{array}{c}0.181 \\
(0.254)\end{array}$ & $\begin{array}{c}0.174 \\
(0.253)\end{array}$ & $\begin{array}{c}0.233 \\
(0.262)\end{array}$ & $\begin{array}{c}0.182 \\
(0.253)\end{array}$ & $\begin{array}{c}0.212 \\
(0.256)\end{array}$ & $(0.264)$ \\
\hline Number parties $_{t-1}$ & $\begin{array}{c}-0.173^{*} \\
(0.099)\end{array}$ & $\begin{array}{l}-0.185^{*} \\
(0.102)\end{array}$ & $\begin{array}{c}-0.183^{*} \\
(0.102)\end{array}$ & $\begin{array}{l}-0.157 \\
(0.096)\end{array}$ & $\begin{array}{c}-0.180^{*} \\
(0.097)\end{array}$ & $\begin{array}{c}-0.231^{* *} \\
(0.102)\end{array}$ \\
\hline Investment price $_{t-1}$ & $\begin{array}{l}-0.014 \\
(0.013)\end{array}$ & $\begin{array}{l}-0.014 \\
(0.013)\end{array}$ & $\begin{array}{l}-0.016 \\
(0.013)\end{array}$ & $\begin{array}{l}-0.011 \\
(0.013)\end{array}$ & $\begin{array}{l}-0.016 \\
(0.012)\end{array}$ & $\begin{array}{l}-0.016 \\
(0.012)\end{array}$ \\
\hline Population growth ${ }_{t}$ & $\begin{array}{c}0.575 \\
(0.358)\end{array}$ & $\begin{array}{l}0.615^{*} \\
(0.352)\end{array}$ & $\begin{array}{c}0.578 \\
(0.358)\end{array}$ & $\begin{array}{l}0.619^{*} \\
(0.339)\end{array}$ & $\begin{array}{c}0.552 \\
(0.331)\end{array}$ & $\begin{array}{l}0.615^{*} \\
(0.345)\end{array}$ \\
\hline Public expenditure $_{t-1}$ & $\begin{array}{l}-0.153 \\
(0.105)\end{array}$ & $\begin{array}{l}-0.142 \\
(0.104)\end{array}$ & $\begin{array}{l}-0.149 \\
(0.098)\end{array}$ & $\begin{array}{l}-0.170 \\
(0.106)\end{array}$ & $\begin{array}{l}-0.160 \\
(0.104)\end{array}$ & $\begin{array}{c}-0.163^{*} \\
(0.095)\end{array}$ \\
\hline Enrollment secondary $_{t}$ & $\begin{array}{c}0.003 \\
(0.011)\end{array}$ & $\begin{array}{c}0.004 \\
(0.011)\end{array}$ & $\begin{array}{l}-0.001 \\
(0.010)\end{array}$ & $\begin{array}{c}0.001 \\
(0.011)\end{array}$ & $\begin{array}{c}0.005 \\
(0.011)\end{array}$ & $\begin{array}{l}-0.002 \\
(0.010)\end{array}$ \\
\hline Globalization $_{t}$ & $\begin{array}{l}-0.091 \\
(0.055)\end{array}$ & $\begin{array}{l}-0.094^{*} \\
(0.054)\end{array}$ & $\begin{array}{l}-0.109^{*} \\
(0.054)\end{array}$ & $\begin{array}{c}-0.106^{*} \\
(0.053)\end{array}$ & $\begin{array}{l}-0.086 \\
(0.052)\end{array}$ & $\begin{array}{c}-0.115^{* *} \\
(0.049)\end{array}$ \\
\hline Inflation $_{t-1}$ & $\begin{array}{l}-0.070 \\
(0.043)\end{array}$ & $\begin{array}{l}-0.067 \\
(0.043)\end{array}$ & $\begin{array}{l}-0.069 \\
(0.041)\end{array}$ & $\begin{array}{c}-0.074^{*} \\
(0.042)\end{array}$ & $\begin{array}{l}-0.067 \\
(0.041)\end{array}$ & $\begin{array}{c}-0.070^{*} \\
(0.038)\end{array}$ \\
\hline Fertility rate $_{t}$ & $\begin{array}{l}-1.012^{*} \\
(0.524)\end{array}$ & $\begin{array}{l}-1.095^{*} \\
(0.528)\end{array}$ & $\begin{array}{l}-0.769 \\
(0.505)\end{array}$ & $\begin{array}{l}-0.868 \\
(0.537)\end{array}$ & $\begin{array}{l}-1.036^{*} \\
(0.538)\end{array}$ & $\begin{array}{c}-1.138^{* *} \\
(0.480)\end{array}$ \\
\hline Urban & $\begin{array}{l}-0.008 \\
(0.047)\end{array}$ & $\begin{array}{c}0.017 \\
(0.046)\end{array}$ & $\begin{array}{l}-0.030 \\
(0.044)\end{array}$ & $\begin{array}{l}-0.001 \\
(0.046)\end{array}$ & $\begin{array}{l}-0.014 \\
(0.046)\end{array}$ & $\begin{array}{l}-0.030 \\
(0.045)\end{array}$ \\
\hline Constant & $\begin{array}{l}12.837 \\
(9.055)\end{array}$ & $\begin{array}{l}12.608 \\
(9.077)\end{array}$ & $\begin{array}{c}15.990 \\
(10.081)\end{array}$ & $\begin{array}{l}12.886 \\
(8.811)\end{array}$ & $\begin{array}{l}14.320 \\
(8.645)\end{array}$ & $\begin{array}{l}18.812 \\
(8.759)\end{array}$ \\
\hline Country FE & yes & yes & yes & yes & yes & yes \\
\hline Period Dummies & yes & yes & yes & yes & yes & yes \\
\hline Observations & 753 & 753 & 753 & 753 & 753 & 753 \\
\hline R-squared & 0.35 & 0.35 & 0.36 & 0.36 & 0.35 & 0.38 \\
\hline
\end{tabular}
at the $5 \%$ level. $* * *$ Significant at the $1 \%$ level

We want to investigate this more closely and regress the changes of the ideology variables on the GDP growth rates of the respective year and the preceding year, plus the full set of control variables used before (since no other variable is statistically significant in more than one regression, their results are omitted in the summary table). The results are summarised in Table 7 . As can be seen, all variables have the sign which would 
Table 7: Summary of regression results: explanation of ideology changes

\begin{tabular}{|c|c|c|}
\hline \multirow[b]{2}{*}{ Dependent variable } & \multicolumn{2}{|c|}{ Explanatory variables } \\
\hline & GDP growth $t$ & GDP growth gr-1 $_{t}$ \\
\hline \multirow[t]{2}{*}{$\Delta$ Left-right $(\mathrm{CMP})_{t-1}$} & -0.110 & -0.122 \\
\hline & $(0.086)$ & $(0.113)$ \\
\hline \multirow[t]{2}{*}{$\Delta$ Interventions $_{t-1}$} & -0.060 & -0.002 \\
\hline & $(0.037)$ & $(0.028)$ \\
\hline \multirow{2}{*}{$\Delta$ Technology and Infrastructure ${ }_{t-1}$} & $-0.061^{* *}$ & -0.038 \\
\hline & $(0.028)$ & $(0.043)$ \\
\hline \multirow[t]{2}{*}{$\Delta$ Incentives for Business $t-1$} & -0.010 & -0.050 \\
\hline & $(0.051)$ & $(0.041)$ \\
\hline \multirow[t]{2}{*}{$\Delta$ Economic Orthodoxy $t-1$} & -0.029 & 0.002 \\
\hline & $(0.021)$ & $(0.029)$ \\
\hline \multirow[t]{2}{*}{$\Delta$ Institutions $_{t-1}$} & 0.010 & -0.025 \\
\hline & $(0.072)$ & $(0.076)$ \\
\hline \multirow[t]{2}{*}{$\Delta$ Decentralisation $_{t-1}$} & 0.005 & -0.008 \\
\hline & $(0.018)$ & $(0.017)$ \\
\hline \multirow[t]{2}{*}{$\Delta$ Welfare State (narrow) $t-1$} & $0.114^{* *}$ & 0.020 \\
\hline & $(0.064)$ & $(0.043)$ \\
\hline \multirow[t]{2}{*}{$\Delta$ Welfare State $(\text { broad })_{t-1}$} & $0.193^{* *}$ & 0.083 \\
\hline & $(0.074)$ & $(0.058)$ \\
\hline
\end{tabular}

Observations: 753 in all regressions. The estimations contain country fixed effects and period dummies. The full set of control variables applied in table 3. Robust standard errors allowing for autocorrelation and heteroscedasticity in parentheses: * Significant at the $10 \%$ level. ** Significant at the $5 \%$ level. *** Significant at the $1 \%$ level.

be predicted by our assumption, i.e. in years of low growth rates the positions of the legislatures tended to shift to more right-wing (or market liberal) positions. This might be induced by higher vote shares for right-wing parties or platform shifts of the parties to the right. Yet, this effect is moderate in most cases, since all coefficients except the Technology and Infrastructure and the Welfare State variables are not statistically significant .

Although the endogeneity problem does not seem to be very substantive from a quantitative perspective, we want to address the issue in the best possible way. Unfortunately, there are no reasonable instruments available for our political variables. Instead, we check the robustness of our previous results by omitting the observations in the years subsequent to elections. At this point of time, the mechanism sketched above should have the strongest impact, so this will be corrected by our procedure. We expect that in our previous estimates the coefficients are biased downward since in recession years the legislatures tend to shift to more market liberal positions as we have just demonstrated. Thus, these more market liberal positions would be linked with the still lower growth rate in the subsequent year.

In Table 8, the regressions for the main variables are rerun after excluding those observations for years subsequent to election years. The results are qualitatively in line with those presented above and the quantitative differences are modest as well. The t-values of our variables of interest, however, are slightly higher than before in most cases, which 
Table 8: Regression results: post-election years dropped

\begin{tabular}{|c|c|c|c|c|c|c|}
\hline Left-right (CMP) & $\begin{array}{c}0.023^{* *} \\
(0.009)\end{array}$ & & & & & \\
\hline Interventions & & $\begin{array}{c}-0.077^{* *} \\
(0.032)\end{array}$ & & & & $\begin{array}{c}-0.098^{* * *} \\
(0.031)\end{array}$ \\
\hline Technology and Infrastructure & & & $\begin{array}{c}0.134^{* *} \\
(0.048)\end{array}$ & & & $\begin{array}{c}0.122^{* *} \\
(0.047)\end{array}$ \\
\hline Incentives for Business & & & & $\begin{array}{c}0.144^{* * *} \\
(0.035)\end{array}$ & & $\begin{array}{c}0.108^{* * *} \\
(0.035)\end{array}$ \\
\hline Welfare State (broad) & & & & & $\begin{array}{c}-0.070^{* * *} \\
(0.019)\end{array}$ & $\begin{array}{c}-0.037^{* *} \\
(0.016)\end{array}$ \\
\hline Economic Orthodoxy & & & & & & $\begin{array}{c}-0.092^{* *} \\
(0.042)\end{array}$ \\
\hline Institutions & & & & & & $\begin{array}{c}0.018 \\
(0.015)\end{array}$ \\
\hline Decentralisation & & & & & & $\begin{array}{l}-0.062 \\
(0.067)\end{array}$ \\
\hline GDP per capita $t-1$ & $\begin{array}{c}-0.170^{*} \\
(0.082)\end{array}$ & $\begin{array}{c}-0.170^{*} \\
(0.085)\end{array}$ & $\begin{array}{c}-0.182 * \\
(0.078)\end{array}$ & $\begin{array}{c}-0.195^{* *} \\
(0.083)\end{array}$ & $\begin{array}{c}-0.191^{* *} \\
(0.080)\end{array}$ & $\begin{array}{c}-0.217^{* *} \\
(0.079)\end{array}$ \\
\hline Population share $15-64_{t}$ & $\begin{array}{c}0.205 \\
(0.147)\end{array}$ & $\begin{array}{c}0.208 \\
(0.149)\end{array}$ & $\begin{array}{c}0.187 \\
(0.161)\end{array}$ & $\begin{array}{c}0.191 \\
(0.141)\end{array}$ & $\begin{array}{c}0.184 \\
(0.137)\end{array}$ & $\begin{array}{c}0.158 \\
(0.144)\end{array}$ \\
\hline Investment share $_{t-1}$ & $\begin{array}{l}-0.013 \\
(0.027)\end{array}$ & $\begin{array}{l}-0.015 \\
(0.024)\end{array}$ & $\begin{array}{l}-0.018 \\
(0.029)\end{array}$ & $\begin{array}{l}-0.021 \\
(0.029)\end{array}$ & $\begin{array}{l}-0.011 \\
(0.026)\end{array}$ & $\begin{array}{l}-0.021 \\
(0.026)\end{array}$ \\
\hline Number parties $_{t-1}$ & $\begin{array}{l}-0.010 \\
(0.098)\end{array}$ & $\begin{array}{l}-0.032 \\
(0.102)\end{array}$ & $\begin{array}{l}-0.029 \\
(0.110)\end{array}$ & $\begin{array}{c}0.011 \\
(0.094)\end{array}$ & $\begin{array}{l}-0.026 \\
(0.096)\end{array}$ & $\begin{array}{l}-0.097 \\
(0.115)\end{array}$ \\
\hline Investment price $_{t-1}$ & $\begin{array}{l}-0.019 \\
(0.017)\end{array}$ & $\begin{array}{l}-0.021 \\
(0.018)\end{array}$ & $\begin{array}{l}-0.024 \\
(0.017)\end{array}$ & $\begin{array}{l}-0.016 \\
(0.017)\end{array}$ & $\begin{array}{l}-0.020 \\
(0.016)\end{array}$ & $\begin{array}{l}-0.022 \\
(0.015)\end{array}$ \\
\hline Population growth ${ }_{t}$ & $\begin{array}{c}0.783^{* *} \\
(0.377)\end{array}$ & $\begin{array}{c}0.833^{* *} \\
(0.370)\end{array}$ & $\begin{array}{l}0.734^{*} \\
(0.380)\end{array}$ & $\begin{array}{c}0.805^{* *} \\
(0.374)\end{array}$ & $\begin{array}{l}0.740^{*} \\
(0.363)\end{array}$ & $\begin{array}{c}0.815 \\
(0.370)\end{array}$ \\
\hline Public expenditure $_{t-1}$ & $\begin{array}{l}-0.211 \\
(0.162)\end{array}$ & $\begin{array}{l}-0.205 \\
(0.161)\end{array}$ & $\begin{array}{l}-0.206 \\
(0.155)\end{array}$ & $\begin{array}{l}-0.234 \\
(0.162)\end{array}$ & $\begin{array}{l}-0.228 \\
(0.159)\end{array}$ & $\begin{array}{l}-0.221 \\
(0.141)\end{array}$ \\
\hline Enrollment secondary $t$ & $\begin{array}{c}0.002 \\
(0.013)\end{array}$ & $\begin{array}{c}0.003 \\
(0.013)\end{array}$ & $\begin{array}{l}-0.008 \\
(0.012)\end{array}$ & $\begin{array}{l}-0.000 \\
(0.013)\end{array}$ & $\begin{array}{c}0.005 \\
(0.013)\end{array}$ & $\begin{array}{l}-0.003 \\
(0.012)\end{array}$ \\
\hline Globalization $_{t}$ & $\begin{array}{c}-0.130^{* *} \\
(0.052)\end{array}$ & $\begin{array}{c}-0.131^{* *} \\
(0.052)\end{array}$ & $\begin{array}{c}-0.151^{* * *} \\
(0.052)\end{array}$ & $\begin{array}{c}-0.155^{* * *} \\
(0.051)\end{array}$ & $\begin{array}{c}-0.129^{* *} \\
(0.049)\end{array}$ & $\begin{array}{c}-0.152^{* * *} \\
(0.042)\end{array}$ \\
\hline Inflation $_{t-1}$ & $\begin{array}{c}-0.126^{* * *} \\
(0.035)\end{array}$ & $\begin{array}{c}-0.118^{* * *} \\
(0.034)\end{array}$ & $\begin{array}{c}-0.119^{* * *} \\
(0.033)\end{array}$ & $\begin{array}{c}-0.128^{* * *} \\
(0.035)\end{array}$ & $\begin{array}{c}-0.120^{* * *} \\
(0.032)\end{array}$ & $\begin{array}{c}-0.126^{* * *} \\
(0.029)\end{array}$ \\
\hline 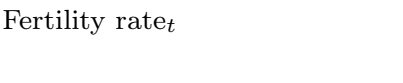 & $\begin{array}{c}-1.117^{* *} \\
(0.536)\end{array}$ & $\begin{array}{c}-1.183^{* *} \\
(0.504)\end{array}$ & $\begin{array}{c}-0.726 \\
(0.505)\end{array}$ & $\begin{array}{l}-0.809 \\
(0.546)\end{array}$ & $\begin{array}{c}-1.001^{*} \\
(0.509)\end{array}$ & $\begin{array}{c}-1.381^{* *} \\
(0.554)\end{array}$ \\
\hline Urban & $\begin{array}{c}0.015 \\
(0.055)\end{array}$ & $\begin{array}{c}0.000 \\
(0.053)\end{array}$ & $\begin{array}{l}-0.025 \\
(0.049)\end{array}$ & $\begin{array}{c}0.016 \\
(0.051)\end{array}$ & $\begin{array}{l}-0.002 \\
(0.052)\end{array}$ & $\begin{array}{c}0.001 \\
(0.049)\end{array}$ \\
\hline Constant & $\begin{array}{c}6.980 \\
(11.397)\end{array}$ & $\begin{array}{c}8.269 \\
(11.829)\end{array}$ & $\begin{array}{c}11.735 \\
(12.566)\end{array}$ & $\begin{array}{c}8.475 \\
(10.893)\end{array}$ & $\begin{array}{c}10.697 \\
(10.648)\end{array}$ & $\begin{array}{c}14.325 \\
(11.367)\end{array}$ \\
\hline Country FE & yes & yes & yes & yes & yes & yes \\
\hline Period Dummies & yes & yes & yes & yes & yes & yes \\
\hline Observations & 535 & 535 & 535 & 535 & 535 & 535 \\
\hline R-squared & 0.41 & 0.41 & 0.42 & 0.42 & 0.42 & 0.45 \\
\hline
\end{tabular}

Robust standard errors allowing for autocorrelation and heteroscedasticity in parentheses: * Significant at the $10 \%$ level. $* *$ Significant at the $5 \%$ level. $* * *$ Significant at the $1 \%$ level.

confirms our expectation that the earlier estimations were marginally biased downward. Consequently, we can conclude that the endogeneity problem does not seem quantitatively important and that it even leads to an underestimation of the measured effects; so the coefficients presented above have to be regarded as lower boundaries of the true effects. 


\section{Discussion}

Our results imply that the political environment matters for the performance of the economy in democratic societies. Although this conclusion should not be very surprising to policy advisers or political observers, the empirical literature has always found it difficult to confirm this claim. The possible channels of a political influence on the economic performance are diverse and complex, so our consideration of policy preferences based on manifesto data offers a new approach to quantify the political environment.

In particular, the most usual simplification of ideology, which is a simple left-right classification of the government according to party labels, is shown to be uncapable of explaining differences in the economic performance of OECD countries. In this regard, our measures derived from party manifesto data offer the opportunity to assess the preferences of political parties in a more detailed way. They are not based on the simple characterization of parties as left-wing or right-wing, but on their actual programmatic profile, which represents their political preferences. Considering these party preferences. We are thus able to identify an impact of party preferences for certain policy issues.

Our approach can be regarded as a complement to several related findings that study an effect of politics on growth based on measurable political actions, such as expenditures. Both approaches have their specific drawbacks: our measures of political preferences are obviously not a perfect correlate with policies which are actually implemented. On the other side, the related literature which is mainly based on narrow expenditure measures is not capable of incorporating political decisions which do not involve the public budget or only impact on the expectations of the market participants. Interestingly, the results of both approaches are along the same lines when it comes to the impact of disaggregated policy areas.

Nonetheless, our results pose some new questions. The detected effects mainly suggest a positive impact of an investment-friendly political environment and are well in line with the predictions from growth theory. Yet, their size and speed are astonishing. Growth theory predicts such growth-enhancing (or growth-depressing) consequences of public interventions to materialize rather in the medium and long term and not as fast as our results indicate. Moreover, concerns related to the practical conduct of public policy, such as decision and implementation lags, also militate against the presumption that the identified effects are mainly the result of real interventions of politics, such as public expenditure or 
non-budgetary regulations. Consequently, there is a high probability that many of these effects are actually transmitted via the expectations of the market participants, which are shaped by the political environment. This issue, however, is highly unexplored in the economic literature, so we are only able to speculate about its relevance.

Furthermore, it is important to stress that our findings should not give rise to misunderstandings concerning the political implications. First, although we found that party preferences for certain policy areas turn out to have a significant impact on economic performance, we could not detect an impact of party ideology based on the party family approach. Hence, growth-stimulating economic policy does not depend on the question whether a left-wing or right-wing party is in office. It rather depends on the actual programmatic profile of the party, although it cannot be denied that the identified growthenhancing policies can be broadly categorized as economic liberal policies. Second, we analysed the effect on short-term economic performance and not on long-term economic growth, which would require a completely different research design. Thus, positive effects of certain policies only accruing in the long-term perspective, which for instance can be expected of investments in education, cannot be captured by our analysis.

\section{References}

Agell, J., H. Ohlsson, and P. S. Thoursie (2006): "Growth Effects of Government Expenditure and Taxation in Rich Countries: A Comment," European Economic Review, 50(1), 211-218.

Amable, B., D. Gatti, and J. Schumacher (2006): "Welfare-State Retrenchment: The Partisan Effect Revisited," Oxford Review of Economic Policy, 22(1), 426-444.

Angelopoulos, K., G. Economides, and P. Kammas (2007): "Tax-Spending Policies and Economic Growth: Theoretical Predictions and Evidence from the OECD," European Journal of Political Economy, 23(4), 885-902.

(2009): "Do Political Incentives Matter for Tax Policies? Ideology, Opportunism and the Tax Structure," Department of Economics, University of Glasgow Working Paper no. 2009-12. 
Baier, S. L., And G. Glomm (2001): "Long-Run Growth and Welfare Effects of Public Policies with Distortionary Taxation," Journal of Economic Dynamics \&f Control, 25(12), 2007-2042.

BanerJee, A. V., And E. Duflo (2003): "Inequality and Growth: What Can the Data Say?," Journal of Economic Growth, 8(3), 267-299.

Barro, R. J. (1990): "Government Spending in a Simple Model of Endogeneous Growth," Journal of Political Economy, 98(5), S103-S125.

Baskaran, T., And L. P. Feld (2009): "Fiscal Decentralization and Economic Growth in OECD Countries: Is there a Relationship?," CESIfo Working Paper No. 2721, Munich.

Bassanini, A., And S. Scarpetta (2001): "The Driving Forces of Economic Growth: Panel Data Evidence for the OECD Countries," OECD Economic Studies, 33(2), 9-56.

Beck, T., G. Clarke, A. Groff, P. Keefer, and P. Walsh (2001): "New Tools in Comparative Political Economy: The Database of Political Institutions," World Bank Economic Review, 15(1), 165-176.

Benoit, K., And M. Laver (2006): Party Policy in Modern Democracies. Cambridge University Press, Cambridge.

Berggren, N., And H. Jordahl (2005): "Does Free Trade Really Reduce Growth? Further Testing Using the Economic Freedom Index," Public Choice, 122(1-2), 99-114.

Bergh, A., And M. Karlsson (2010): "Government Size and Growth: Accounting for Economic Freedom and Globalization," Public Choice, 142(1-2), 195-213.

Bjørnskov, C. (2005): "Does Political Ideology Affect Economic Growth?," Public Choice, 123(1), 133-146.

BrÄUninger, T. (2005): "A Partisan Model of Government Expenditure," Public Choice, 125(3-4), 409-429.

Brock, W. A., and S. N. Durlauf (2001): "What Have We Learned from a Decade of Empirical Research on Growth? Growth Empirics and Reality," The World Bank Economic Review, 15(2), 229-272. 
Budge, I. (2001): "Validating the Manifesto Research Group Approach," in Estimating the Policy Positions of Political Actors, ed. by M. Laver, pp. 50-65. Routhledge.

Budge, I., and R. I. Hofferbert (1990): "Mandates and Policy Outputs: U.S. Party Platforms and Federal Expenditures," The American Political Science Review, 84(1), $111-131$.

Budge, I., H.-D. Klingemann, A. Volkens, J. Bara, and E. Tanenbaum (2001): Mapping Policy Preferences: Estimates for Parties, Electors, and Governments 19451998. Oxford University Press, Oxford.

Budge, I., D. Robertson, And D. Hearl (1987): Ideology, Strategy, and Party Change: Spatial Analyses of Post-War Election Programmes in 19 Democracies. Cambridge University Press, Cambridge.

Calvert, R. L. (1985): "Robustness of the Multidimensional Voting Model: Candidate Motivations, Uncertainty, and Convergence," American Journal of Political Science, 29(1), 69-95.

Cusack, T. R. (1997): "Partisan Politics and Public Finance: Changes in Public Spending in the Industrialized Democracies, 1955-1989," Public Choice, 91(3-4), 375-395.

Cusack, T. R., And L. Engelhardt (2002): "The PGL File Collection: File Structures and Procedures," Wissenschaftszentrum Berlin für Sozialforschung.

Debus, M. (2009): "Analysing Party Politics in Germany with New Approaches for Estimating Policy Preferences of Political Actors," German Politics, 18(3), 281-300.

Doucouliagos, C., And M. A. Ulubasoglu (2006): "Economic Freedom and Economic Growth: Does Specification Make a Difference?," European Journal of Political Economy, 22(1), 60-81.

Drazen, A. (2000): Political Economy in Macroeconomics. Princeton University Press, Princeton.

Dreher, A. (2006): "Does Globalization Affect Growth? Evidence from a new Index of Globalization," Applied Economics, 38(10), 1091-1110. 
Durlauf, S. N., P. A. Johnson, and J. R. Temple (2005): "Growth Econometrics," in Handbook of Economic Growth, ed. by P. Aghion, and S. N. Durlauf, vol. 1A, pp. 555-677. Elsevier.

Durlauf, S. N., A. Kourtellos, and C. M. Tan (2008): “Are Any Growth Theories Robust?," The Economic Journal, 118(3), 329-346.

Duso, T., AND L.-H. RÖLler (2003): "Endogenous Deregulation: Evidence from OECD Countries," Economics Letters, 81(1), 67-71.

Duso, T., And J. Seldeslachts (2010): "The Political Economy of Mobile Telecommunications Liberalization: Evidence from the OECD Countries," Journal of Comparative Economics, 38(2), 199-216.

FÜss, R., And M. M. Bechtel (2007): "Partisan Politics and Stock Market Performance: The Effect of Expected Government Partisanship on Stock Returns in the 2002 German Federal Election," Public Choice, 135(3-4), 131-150.

Gerber, A. S., And G. A. Huber (2009): "Partisanship and Economic Behavior: Do Partisan Differences in Economic Forecasts Predict Real Economic Behavior?," American Political Science Review, 103(3), 407-426.

(2010): "Partisanship, Political Control, and Economic Assessments," American Journal of Political Science, 54(1), 153-173.

Geys, B., And R. Nuscheler (2010): "Public Health Care Spending in the OECD: The Role of Partisan Cycles and Campaign Promises," Wissenschaftszentrum Berlin, mimeo.

HaAn, J. D., S. Lundström, And J.-E. Sturm (2006): "Market-Oriented Institutions and Policies and Economic Growth: A Critical Survey," Journal of Economic Surveys, 20(2), 157-191.

Hofferbert, R. I., And I. Budge (1992): "The Party Mandate and the Westminster Model: Election Programmes and Government Spending in Britain, 1948-85," British Journal of Political Science, 22(2), 151-182.

Irmen, A., And J. Kuehnel (2009): "Productive Government Expenditure and Economic Growth," Journal of Economic Surveys, 23(4), 692-733. 
Islam, N. (2003): "What Have We Learnt from the Convergence Debate?," Journal of Economic Surveys, 17(3), 309-362.

Kneller, R., M. F. Bleaney, and N. Gemmell (1999): "Fiscal Policy and Growth: Evidence from OECD Countries," Journal of Public Economics, 74(2), 171-190.

Knill, C., M. Debus, And S. Heichel (2010): "Do Parties Matter in Internationalized Policy Areas? The Impact of Political Parties on Environmental Policy Outputs in 18 OECD Countries 1970-2000," European Journal of Political Research, 49(3), 301-336.

Laver, M., and J. Garry (2000): "Estimating Policy Positions from Political Texts," American Journal of Political Science, 44(3), 619-634.

Magnus, J. R., O. Powell, And P. Prüfer (2010): "A Comparison of Two Model Averaging Techniques with an Application to Growth Empirics," Journal of Econometrics, 154(2), 139-153.

McDonald, M. D., And S. M. Mendes (2001): "The Policy Space of Party Manifestos," in Estimating the Policy Positions of Political Actors, ed. by M. Laver, pp. 90-114. Routledge.

Mueller, D. C. (2003): Public Choice III. Cambridge University Press, Cambridge.

Nicoletti, G., And S. Scarpetta (2003): "Regulation, Productivity and Growth: OECD Evidence," Economic Policy, 18(36), 9-72.

Nordhaus, W. D. (1975): "The Political Business Cycle," Review of Economic Studies, 42(2), 169-190.

Persson, T., And G. TABellini (1994): "Is Inequality Harmful for Growth?," The American Economic Review, 84(3), 600-621.

Pitlik, H. (2007): "A Race to Liberalization? Diffusion of Economic Policy Reform among OECD-Economies," Public Choice, 132(1-2), 159-178.

Potrafke, N. (2009): "Did Globalization Restrict Partisan Politics? An Empirical Evaluation of Social Expenditures in a Panel of OECD Countries," Public Choice, 140(1), $105-124$. 
(2010): "Does Government Ideology Influence Deregulation of Product Markets? Empirical Evidence from OECD Countries," Public Choice, 143(1-2), 135-155.

Quinn, D. P., And A. M. Toyoda (2007): "Ideology and Voter Preferences as Determinants of Financial Globalization," American Journal of Political Science, 51(2), $344-363$.

Romer, C. D., And D. H. Romer (2010): "The Macroeconomic Effects of Tax Changes: Estimates Based on a New Measure of Fiscal Shocks," American Economic Review, $100(3), 763801$.

Romp, W., And J. DE HAAn (2007): "Public Capital and Economic Growth: A Critical Survey," Perspektiven der Wirtschaftspolitik, 8(S1), 6-52.

Roubini, N., And J. Sachs (1989): "Government Spending and Budget Deficits in the Industrial Countries," Economic Policy, 4(8), 100-132.

Sala-I-Martin, X., G. Doppelhofer, and R. I. Miller (2004): "Determinants of Long-Term Growth: A Bayesian Averaging of Classical Estimates (BACE) Approach," The American Economic Review, 94(4), 813-835.

Snowberg, E., J. Wolfers, and E. Zitzewitz (2007): "Partisan Impacts on the Economy: Evidence from Prediction Markets and Close Elections," The Quarterly Journal of Economics, 122(2), 807-829.

Stevenson, R. T. (2001): "The Economy and Policy Mood: A Fundamental Dynamic of Democratic Politics?," American Journal of Political Science, 45(3), 620-633.

Thornton, J. (2007): "Fiscal Decentralization and Economic Growth Reconsidered," Journal of Urban Economics, 61(1), 64-70.

Wittman, D. (1977): "Candidates with Policy Preferences: A Dynamic Model," Journal of Economic Theory, 14(1), 180-189. 


\section{Appendix}

Table 9: Descriptive statistics of policy preferences measures

\begin{tabular}{lcccc}
\hline & Mean & Std. Dev. & Min & Max \\
\hline \hline Right-left dimension & -2.62 & 12.41 & -31.42 & 39.71 \\
Interventions & 2.05 & 3.73 & -7.57 & 15.97 \\
Technology and Infrastructure & 5.23 & 3.29 & 0.07 & 19.79 \\
Economic Orthodoxy & 2.62 & 2.83 & -2.07 & 18.27 \\
Incentives for Business & 5.39 & 3.47 & 0 & 26.09 \\
Institutions & 17.02 & 8.01 & 3.09 & 46.64 \\
Decentralisation & 2.08 & 1.90 & -3.82 & 12.94 \\
Welfare State (narrow) & 11.29 & 5.15 & 0.89 & 31.79 \\
Welfare State (broad) & 19.51 & 6.39 & 1.21 & 51.21 \\
\hline
\end{tabular}

Table 10: Correlations of policy preferences measures

\begin{tabular}{lcccccccc}
\hline & $(1)$ & $(2)$ & $(3)$ & $(4)$ & $(5)$ & $(6)$ & $(7)$ & $(8)$ \\
\hline \hline (1) Interventions & 1 & & & & & & & \\
(2) Technology and Infrastructure & -0.03 & 1 & & & & & & \\
(3) Economic Orthodoxy & -0.23 & -0.08 & 1 & & & & & \\
(4) Incentives for Business & -0.02 & 0.17 & 0.07 & 1 & & & & \\
(5) Institutions & -0.07 & -0.13 & -0.02 & -0.25 & 1 & & & \\
(6) Decentralisation & 0.06 & -0.08 & -0.11 & 0.00 & -0.02 & 1 & & \\
(7) Welfare State (narrow) & 0.22 & -0.13 & 0.01 & -0.02 & -0.2 & -0.08 & 1 & \\
(8) Welfare State (broad) & 0.20 & -0.12 & -0.07 & -0.16 & -0.29 & -0.08 & 0.75 & 1 \\
\hline
\end{tabular}


Table 11: Descriptive Statistics, control variables

\begin{tabular}{|c|c|c|c|c|c|c|}
\hline Variable & Description & Mean & $\begin{array}{l}\text { Std. } \\
\text { Dev. }\end{array}$ & Min & Max & Source \\
\hline $\begin{array}{l}\Delta \text { GDP per } \\
\text { capita }\end{array}$ & $\begin{array}{l}\text { Growth rate of real GDP per } \\
\text { capita, in } \%\end{array}$ & 2.52 & 2.75 & -9.75 & 16.67 & $\begin{array}{l}\text { Penn World } \text { Table } \\
\text { Version } 6.2\end{array}$ \\
\hline $\begin{array}{l}\text { GDP per } \\
\text { capita }\end{array}$ & $\begin{array}{l}\text { Level of real GDP per capita (chain } \\
\text { index) divided by } 1,000\end{array}$ & 17.96 & 6.25 & 4.51 & 4.93 & $\begin{array}{l}\text { Penn World } \text { Table } \\
\text { Version } 6.2\end{array}$ \\
\hline DPI & $\begin{array}{l}\text { Position of government (-1: left- } \\
\text { wing) }\end{array}$ & 0.04 & 0.81 & -1 & 1 & $\begin{array}{l}\text { Database of Political } \\
\text { Institutions, see Beck } \\
\text { et al. (2001) }\end{array}$ \\
\hline $\begin{array}{l}\text { Working } \\
\text { age pop. }\end{array}$ & $\begin{array}{l}\text { Population aged } 15-64 \text {, share of to- } \\
\text { tal population in } \%\end{array}$ & 65.21 & 2.69 & 57.1 & 69.8 & $\begin{array}{l}\text { World Development } \\
\text { Indicators }\end{array}$ \\
\hline $\begin{array}{l}\text { Investment } \\
\text { share }\end{array}$ & Share of investments in GDP in \% & 23.76 & 5.78 & -4.37 & 72.82 & $\begin{array}{l}\text { World Development } \\
\text { Indicators }\end{array}$ \\
\hline Election & $\begin{array}{l}\text { Share of months prior to the elec- } \\
\text { tion in the election year }\end{array}$ & 0.17 & 0.31 & 0 & 1 & $\begin{array}{l}\text { own calculations } \\
\text { based on Cusack and } \\
\text { Engelhardt }(2002)\end{array}$ \\
\hline $\begin{array}{l}\text { Number } \\
\text { parties }\end{array}$ & $\begin{array}{l}\text { Number of parties in government } \\
\text { coalition, end of year }\end{array}$ & 2.06 & 1.27 & 1 & 6 & $\begin{array}{l}\text { Cusack and Engel- } \\
\text { hardt }(2002)\end{array}$ \\
\hline $\begin{array}{l}\text { Investment } \\
\text { price }\end{array}$ & $\begin{array}{l}\text { Price Level of Investment in PPP } \\
(\mathrm{USA}=100)\end{array}$ & 88.81 & 21.36 & 39.27 & 171.16 & 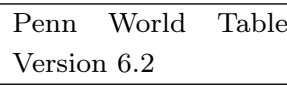 \\
\hline $\begin{array}{l}\text { Pop. } \\
\text { growth }\end{array}$ & Population growth rate in $\%$ & 0.70 & 0.55 & -0.93 & 3.38 & $\begin{array}{l}\text { World Development } \\
\text { Indicators }\end{array}$ \\
\hline $\begin{array}{l}\text { Government } \\
\text { share }\end{array}$ & $\begin{array}{l}\text { Government share of real GDP in } \\
\%\end{array}$ & 16.33 & 4.23 & 4.58 & 27.98 & 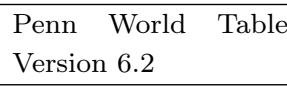 \\
\hline Schooling & $\begin{array}{l}\text { Gross enrollment rate in secondary } \\
\text { education }\end{array}$ & 96.31 & 18.71 & 37.18 & 161.66 & $\begin{array}{l}\text { World Bank Edstat } \\
\text { Database }\end{array}$ \\
\hline Globalization & $\begin{array}{l}\text { KOF globalization index, cor- } \\
\text { rected for flow variables }\end{array}$ & 0.14 & 0.34 & 0 & 1 & $\begin{array}{l}\text { Dreher (2006), } 2008 \\
\text { version }\end{array}$ \\
\hline Inflation & $\begin{array}{l}\text { Annual change of consumer price } \\
\text { index, in } \%\end{array}$ & 6.38 & 6.94 & -0.9 & 84.22 & $\begin{array}{l}\text { World Development } \\
\text { Indicators }\end{array}$ \\
\hline $\begin{array}{l}\text { Fertility } \\
\text { rate }\end{array}$ & Births per woman & 1.97 & 0.58 & 1.15 & 4.11 & $\begin{array}{l}\text { World Development } \\
\text { Indicators }\end{array}$ \\
\hline Urban & Share of urban population, in $\%$ & 72.58 & 12.39 & 39.26 & 97.16 & $\begin{array}{l}\text { World Development } \\
\text { Indicators }\end{array}$ \\
\hline EU member & $\begin{array}{l}\text { Dummy variable for EU member- } \\
\text { ship }\end{array}$ & 0.46 & 0.50 & 0 & 1 & own calculations \\
\hline
\end{tabular}

